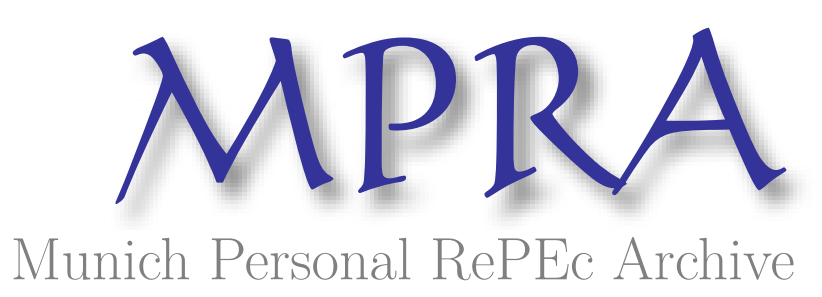

\title{
Non-default Component of Sovereign Emerging Market Yield Spreads and its Determinants: Evidence from Credit Default Swap Market
}

Kucuk, Ugur N.

university of Rome "Tor Vergata"

1 May 2010

Online at https://mpra.ub.uni-muenchen.de/27428/

MPRA Paper No. 27428, posted 17 Dec 2010 00:39 UTC 


\title{
Non-default Component of Sovereign Emerging Market Yield Spreads and its Determinants: Evidence from Credit Default Swap Market*
}

\author{
Uğur N. Küçük ${ }^{\dagger}$
}

(forthcoming in Spring 2010 edition of The Journal of Fixed Income)

\begin{abstract}
In this paper, I show that a sizable component of emerging market sovereign yield spreads is due to factors other than default risk such as liquidity. I estimate the non-default component of the yield spreads as the basis between the actual credit default swap (CDS) premium and the hypothetical CDS premium implied by emerging market bond yields. On average, the basis is large and positive for speculative grade bonds and slightly negative for investment grade bonds. Large positive basis for speculative grade bonds support the existence of speculation in the CDS market when the underling's credit quality is bad. I study the effects of bond liquidity, liquidity in the CDS market, equity market performance and macroeconomic variables on the non-default component of the emerging market yield spreads. I show that bond liquidity has a significant and positive effect on the CDS-bond basis of investment grade bonds. The results suggest that the liquid bonds of investment grade bonds are more expensive relative to the prices implied their CDS premiums. However, the results are somewhat mixed and even contrary for the speculative grade bond sample.
\end{abstract}

JEL Classifications: G10, G12, G15

Keywords: Emerging Market Sovereign Bonds, Credit Risk, Credit Default Swaps, Basis, Liquidity, Emerging Market Equity Markets

\footnotetext{
* This paper was written during my academic visit to Boston College, MA, USA. I am very grateful to Prof. Pierluigi Balduzzi for his valuable advices and suggestions. I would like to thank Prof. Akin Sayrak, Prof. Gustavo Piga and Prof. Leonardo Becchetti for their valuable comments and suggestions during my presentations at Sabanci University and University of Rome II.

${ }^{\dagger}$ Contact: PhD in Money and Finance, Faculty of Economics, Via Columbia 2, 00133, Rome, Italy.

Email kucuk@economia.uniroma2.it Tel: 00393288113181
} 


\section{Contents}

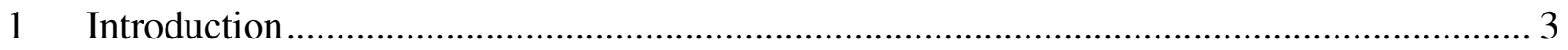

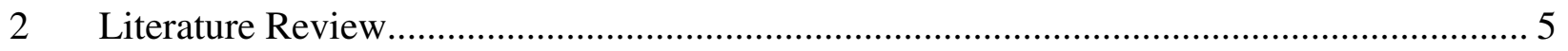

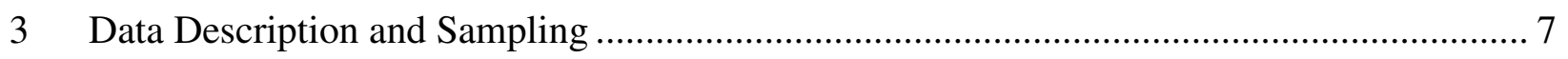

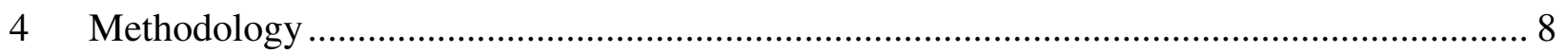

4.1 Par-equivalent Bond Yield Spread....................................................................... 8

4.2 Pricing of Risky and Risk-free Bonds and Extracting the Probability of Default ......... 11

4.3 The Hypothetical CDS Premium Implied by the Probability of Default and Maturity of a Risky Bond:............................................................................................................. 12

4.4 Distribution of CDS-Par equivalent bond yield Basis and Bond Specific Variables ... 13

4.5 Bond and Credit Default Swap Liquidity Variables ................................................... 15

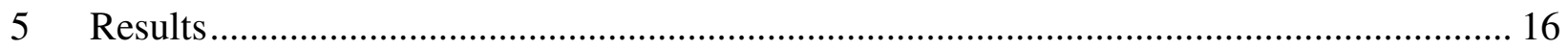

5.1 Correlations among liquidity variables:............................................................... 16

5.2 Determinants of Bond Illiquidity:............................................................................. 16

5.3 Determinants of CDS-Bond Basis: ...................................................................... 17

5.3.1 Emerging Market Bond Liquidity ....................................................................... 17

5.3.2 Emerging Market CDS Market Liquidity ……..................................................... 19

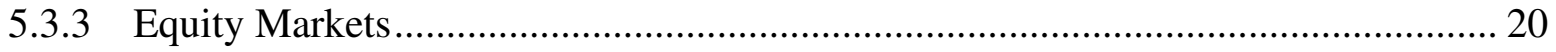

5.3.4 Effects of World-wide Macroeconomic Conditions .................................................. 21

5.3.4 Credit Risk and CDS-Bond Basis:..................................................................... 22

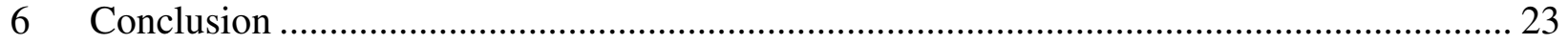

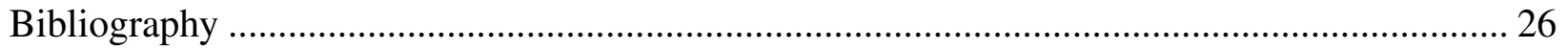

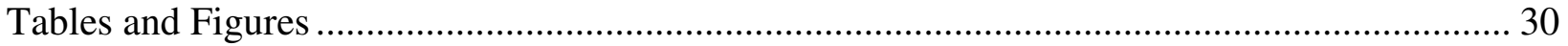




\section{Introduction}

Over the past 10 years, emerging market sovereign bonds handily outperformed not only U.S. corporate bonds, but the S\&P 500 equity index as well. Emerging market bonds are a very large and fast growing asset class; their trade volume in the world is expected to approach $\$ 8$ trillion in 2008. Since emerging market economies carry a considerable default risk, they offer a yield a significant spread relative to their riskless counterparts. However, not the entire yield spread of an emerging market bond can be explained by the default risk alone. Recent studies on the US corporate bond market have noted that factors such as liquidity, taxes, and aggregate market risk also play important roles in corporate yield spreads. Therefore, it is interesting to explain; to what extent sovereign bond yield spreads reflect default risk and how much of their spreads relative to their riskless counterparts stems from factors such as liquidity and other market risk factors.

A derivative instrument called Credit Default Swap (CDS) has become very popular in the last decade. Since CDS prices default risk explicitly, they are a considered as a good benchmark for the pure credit risk of the underlying entity. In this paper, I use CDS premiums to estimate the default and non-default component of emerging market sovereign bond yields and examine the link between the non-default component and liquidity. I study the difference between the CDS premium and the CDS premium as implied by the bond yields as a measure of the nondefault component of the bond yield. ${ }^{3}$ I refer to the difference between the CDS premium and the implied CDS premium as the CDS-bond basis, and I relate the CDS-bond basis to bond liquidity, speculation in the CDS market, CDS liquidity, equity market performance and world macroeconomic factors.

My research has a number of significant contributions to both emerging market debt literature and to the literature on the non-default component of bond yields. First, to the best of my knowledge, this work is the first attempt to identify the non-default components of sovereign bond yield spreads. I use the data on US Dollar denominated bonds, which are issued by 21 emerging market countries and their CDS premiums between January 2004 and May 2008. Second, I improve the literature on calculating the basis between actual CDS and implied CDS

\footnotetext{
${ }^{3}$ The implied CDS premium is premium calculated using the same maturity, default probability and recovery rate implied by the bond yields.
} 
premiums by relaxing the restrictive assumption of a "flat term structure of credit curves". 4 (Figure 1 and 2)

Third, my results on the distribution of the basis, i.e. the non default component, suggest clues about the speculation in the CDS market. This paper is the first one to present evidence on the speculation in the CDS market. My results confirm a large positive basis for speculative grade bonds, which suggests that on average, the CDSs are more expensive than what is implied by their underlying bond yields. When the news about a sovereign is bad, speculators -without owning the underlying bond- might speculate on worsening of the credit conditions of the underlying asset by buying the CDS contract. The excess demand to CDSs would increase the CDS premium while bond prices do not fall as much since the speculation is not directly related to the risk premium of the underlying.

Fourth, I show that liquid bonds investment grade sovereigns are more expensive relative to the price implied by their CDS premiums. For speculative grade bond sample, the results suggest a mixed and even contrary relationship between the bond liquidity and the CDS basis. I use direct bond liquidity proxies such as bid-ask spreads and turnover ratios. I divide the bonds into two rating groups, as investment and speculative grade, in order to distinguish the effects of liquidity on bonds with different credit quality. I illustrate that liquidity has a significant positive effect on the CDS-bond basis of investment grade bonds. Nevertheless, liquidity has a mixed and even contrary effects on the CDS-bond basis of speculative grade bonds. Some possible reasons include; limits to arbitrage due difficulty of short selling the bond and speculation in the CDS market. These are dealt with deeply throughout the paper.

As a novelty for this literature, I report that the domestic stock market performance of emerging markets have a significant negative impact on non-default component of bond yields. The reason for the negative effect seems to be related to credit risk and to the lead-lag relationship between the CDS and bond markets. ${ }^{5}$

The important thing to note is that the focus of this research is emerging market sovereign bond yield spreads. There are some main differences between the US corporate bond market and

\footnotetext{
${ }^{4}$ Longstaff et. $\mathrm{Al}$ (2005) and Nashikkar et al. (2007) assume a flat term structure. However, credit curves are far from being flat (Figure. 1). Therefore, the results established by assuming a flat term structure are prone to be biased.

${ }^{5}$ Blanco et. al. (2006) and Zhu, H. (2006)
} 
emerging market sovereign bond markets. These main differences include: Emerging market sovereigns use only bond financing. By providing large issue sizes and longer maturities in different currencies, they are among the world's largest actors in fixed income markets. The credit event in their CDS contracts is defined differently from those of corporate borrowers since they do not enter directly into the asset liquidation process; instead they rely on debt restructuring processes.

This paper is organized as follows: Section 2 provides a literature review; Section 3 describes the data source and sampling schemes; Section 4 shows the methodology of calculation for the implied CDS premium and the CDS-bond basis; Section 5 discusses the results of my study showing the effects of bond liquidity, CDS liquidity, equity market performances, macroeconomic variables on the non-default component; and finally, Section 6 concludes.

\section{Literature Review}

Early researches have studied the determinants of US corporate yield spreads. On the emerging market literature side, a number of articles have also focused on the determinants of yield spreads. ${ }^{6}$ Some important papers on the determinants of US corporate yield spreads include Jones \& Rosenfeld (1984), Longstaff \& Schwartz (1995), Duffie D. (1999), Elton, Gruber, Mann, \& Mann (2001), Collin-Dufresne, Goldstein, \& Spencer (2001) and Liu, Longstaff, \& Mandell (2006) However, these studies were unable to explain a significant component of the yield spreads, which is not attributable to default risk alone.

Longstaff, Mithal, \& Neis (2005) and later Nashikkar et. al. (2007), Han \& Zhou (2008), Ericsson and Reneby, \& Wang (2007) attempts to identify the default and non default components of the US corporate yield spreads. Longstaff et. al (2005), assuming CDS premiums capture the default related component of the bond yields, use a common credit risk model for both corporate bonds and CDS to indentify the non-default component of the bond yields. They find evidence on the existence of a significant non-default component. Moreover, they show that the bond liquidity as measured by the bid-ask spreads, outstanding amount and coupon rate has a significant explanatory power on the non-default component of bond yields. Nashikkar et. al. (2007) also investigate the relationship between the liquidity and US corporate bond yields and liquidity. They estimate the non-default component, as the basis between the actual CDS and the

\footnotetext{
${ }^{6}$ For researches on emerging market sovereign bond spreads see, Ammer \& Cai (2007), Hund \& Lesmond (2006) and Longstaff, Pan, Pedersen, \& Singleton (2006)
} 
"par-equivalent" corporate bond yield spread. They also find a strong explanatory power of liquidity on the CDS basis. One common drawback of the models used by Longstaff et. al. (2005) and Nashikkar et. al. (2007) is that they assume a flat term structure of credit risk curves. However, the term structure of credit curves is far from being flat. My paper contributes to this literature on identifying and analyzing the determinants of non-default component of yields spreads by examining this relationship in the emerging market debt for the first time. I improve the literature on calculating the basis between actual CDS and implied CDS premiums by relaxing the restrictive assumption of "flat term structure of credit curves" by making full use of CDS maturities from 1 to 10 years.

Blanco et al. (2005) and Zhu H. (2006) document on the co-integration relationship between the corporate bond spreads and CDS premiums. They argue that in the short run, the CDS market leads the corporate bond market in the price discovery process. Zhu, H. (2006) further argues that the short run deviation in is largely due to different responses of the two markets to changes in credit conditions.

The literature on the emerging market bond yield spreads and CDS market is limited. Even though none of the articles are directly related to my research, I present a very brief literature review on the sovereign CDS market. Pan and Singleton (2006), using the CDS pricing model suggested by Duffie and Singleton (2003), show an effort to distinguish between the default risk and the recovery risk in CDS premiums. Chan-Lau and Kim (2004) analyse the co-integration relationship between emerging market CDS premiums and the Emerging Markets Bond Index (EMBI), which is an index covering U.S. Dollar-denominated Brady bonds, loans and Eurobonds. Ammer and Cai (2007) also analyze a co-integration relationship between bond yields and CDS premiums, and report the possibility of the significant impact of cheapest to deliver optionality in CDS premiums. Duffie (1999) shows that under certain conditions, there is an equivalence relationship between CDS premiums and yield spreads on a floating par bond with the same credit risk and maturity. However, since most emerging market bonds are straight fixed-rate, this equivalence does not hold precisely in practice. Therefore, searching for a price discovery relationship between the CDS premiums and the EMBI index or similar indices would result in biased conclusions. 


\section{Data Description and Sampling}

My bond data source is ISMA (the International Securities Market Association), which is the self-regulatory organization and trade association for the international securities market (including the Eurobond market). ISMA TRAX is the ISMA trade matching and regulatory reporting system for the over the counter (OTC) markets. Traded prices, yields and durations are also available on the Datastream system.

I obtain all emerging "traded bond prices" from ISMA TRAX for all traded international US Dollar denominated bonds issued by sovereigns and find the corresponding yield to maturity to use in my par-equivalent bond yield spread calculation.

My bond liquidity variables also come from ISMA TRAX. Bid-ask spreads of sovereign bond prices, average traded daily volume, outstanding market value of bonds and bond specific variables are obtained in a reliable way. Average daily volume for the previous month is calculated by taking the total nominal turnover for an individual bond in the previous month and dividing it by the number of working days in the month.

Since CDS data coverage of CMA via Datastream started on January 2004, my bond data starts from this date as well. The total number of international US Dollar denominated straight fixed rate bonds by emerging market countries reaches $\mathrm{t} 180$. In order to include a particular bond in my sample, the issuer country's CDS contracts must be available for its US Dollar denominated bonds. However, most east European countries have their CDS contracts issued for their Euro denominated bonds, although they have also issued many international bonds on the US Dollar. This fact reduces my sample size of bonds to 107 . The daily data availability together with the fact that $90 \%$ of the bonds cover my entire sample time period provides a sample size of more than 100.000 days.

My CDS data are collected from the Datastream start in January 2004 until May 2008. Quoted CDS mid rate premiums along with their bid-ask spreads are available as daily variables. Data on interest rates, such as swap rates and treasury rates are obtained from Datastream. In my analysis, I use swap rate as the risk free rate, which is now widely believed to be closer to the risk free rate benchmark used by market participants in pricing derivatives.

MSCI is the index used for examining the effects of equity market performances of sovereigns on non-default component of bond yield spreads. MSCI is an index created by Morgan Stanley Capital International (MSCI) that is designed to measure equity market 
performance in global emerging markets. The Emerging Markets Index is a float-adjusted market capitalization index. As of May 2005, it consisted of indices in 26 emerging economies: Argentina, Brazil, Chile, China, Colombia, Czech Republic, Egypt, Hungary, India, Indonesia, Israel, Jordan, Korea, Malaysia, Mexico, Morocco, Pakistan, Peru, Philippines, Poland, Russia, South Africa, Taiwan, Thailand, Turkey and Venezuela

With the purpose of accounting for macroeconomic conditions, the level and slope of US treasury term structure, the return and implied volatilities on the S\&P500 index are exploited. Moody's long term liability ratings for sovereigns are used to group the sample by investment and speculative rating grades. These variables are also available via Datastream.

\section{Methodology}

\subsection{Par-equivalent Bond Yield Spread}

There have been two main approaches to estimate the default component of the bond yield spreads; one uses an explicit model for pricing credit risk while the other relies on CDS premiums. The former approach relies on calibrating a corporate bond pricing model matching historical data on corporate bonds (Huang and Huang, (2003)). The main disadvantage of this approach is that these models are very sensitive to model selection on both default process and risk premium. Considering default events occur at a much smaller frequency in sovereign markets, it becomes even more difficult to estimate the default component by relying on calibration with historical data.

On the other hand, the existence of an efficient and liquid CDS market allows us to isolate default risk in bonds issued by a certain issuer without relying too much on a particular model selection or historical data, since a direct market pricing of credit risk is available in the CDS market.

In fact, Duffie (1999) showed that under certain conditions there is an equivalence relationship between CDS premiums and yield spreads on a floating-rate par bond with the same credit risk. Since most emerging market bonds are fixed-rate bonds, the equivalence suggested by Duffie (1999) does not hold precisely in practice. Longstaff et al. (2005) showed that the basis between the pure corporate bond spread and CDS is a biased measure of the non-default component. 
Another factor complicating the above equivalence relationship stems from the delivery of the reference obligation in the case of a default. In the case of a default, the buyer of the insurance has to deliver an eligible bond to the protection seller in order to get the face value of the bond. Obviously, this deliverable bond will be the cheapest among all deliverable bonds. Moreover, if the deliverable bonds are illiquid, the buyer of the CDS protection may bear additional costs to obtain the bond.

One CDS based approach used to determine default and non-default components of corporate bonds is to use the difference between the CDS premium and the corporate bond yield as a proxy for the non-default component. Han and Zhou (2008) take this approach one step further. They add swap rates to CDS premiums to estimate a CDS-implied par yield curve, and use this curve to bootstrap the zero yield curves and discount the cash flows of each bond to obtain a CDSimplied bond price. They call the difference between actual and CDS-implied bond prices as the basis, i.e. non-default component. However this approach may lead to errors, because the above relationship between CDS premiums and par yields holds only for floating-rate par yield bonds. Considering most of the emerging market bonds have high fixed coupon rates, the majority of the time they sell at a premium. However, CDS protects only up to a bond's face value. So, discounting bonds' cash flows with a zero curve obtained by CDS premiums will most probably be biased.

Longstaff et al. (2005) used a credit risk model to price the CDS and corporate bonds. While this approach addresses the problems of bonds selling at par or discount, it is heavily modeldependent. The literature on credit risk models demonstrates that there remain significant pricing errors in all the models that have been used so far (Nashikkar and Subrahmanyam and Mahanti (2007)).

This paper follows the market participants and uses a method called par-equivalent CDS spread of the bond in order to isolate the non-default component of the bond yields. The problem of deviations of the bond price from its par value is addressed in this method. Since this model does not require any explicit calibration of a credit risk model, it is model independent. In the related paper by Nashikkar and Subrahmanyam, Mahanti (2007), although the authors used a similar method to isolate the non-default component of yield spreads on corporate bonds, they assumed a flat term structure of credit curves. Due to poor CDS maturity diversity, they use only 5 year CDS premium data, although their bond sample included bonds maturing from 1 month to 
40 years. This assumption leads to a major error. As the Mexico example in Figure 1 shows, the term structure of credit risk is far from being flat for emerging markets; rather, its slope is steeply positive. The assumption of flat term structure will lead to biased results of the basis for the bonds with maturities not equal to 5 years. For instance, think about a bond with a maturity of 10 years and a steep upward sloping credit curve. In this case, calculating the 5-year hypothetical par-equivalent CDS spread using the default rates extracted from a 10-year bond assuming constant default rates will cause result in upwards biased hypothetical 5-year CDS premiums. As a result, the basis between the actual 5 year CDS and the par-equivalent CDS premiums will be downwards biased, which will cause errors when measuring the effects of liquidity.

My methodology of isolating the non-default component allows for non-flat credit curve term structures. The details of the methodology of par-equivalent CDS premium and CDS-bond basis is provided in the following section. The methodology to compute the basis is briefly as follows: First, I back out the average probability of default from the market prices of bonds, using swap rates as a risk free curve. Second, using this average probability of default, I compute the expected payoffs of the protection buyer and seller in a hypothetical CDS contract, which has the same maturity as the corresponding bond's remaining maturity. By applying no arbitrage condition, the CDS premium, which makes the expected payoffs of protection buyer and seller equal, is my hypothetical par equivalent CDS premium.

The important virtue of this hypothetical CDS contract is that it has the same maturity of the corresponding bond from which the default probabilities are extracted. Since all emerging market countries in my data sample have CDS dates of maturity from 1 to 10 years, I am able to control for the non-flat term structure of credit curves. The basis for a specific bond is then computed as follows:

$$
\text { Basis }_{i}=C D S_{\text {Actual,i }}-C D S_{\text {Hypothetical }, i}
$$

where $i \in(0,10]$ is the maturity of the corresponding bond. $C D S_{\text {Actual, } i}$ is the market premium of a CDS contract with a maturity of $i$ years. $C D S_{\text {Hypothetical, } i}$ is the implied CDS premium, which is computed by extracting the default probabilities from a bond maturing in $i$ years. Actual CDS premiums for intermediate dates are found by linear interpolation.

Considering the above definition, without liquidity risk, when the basis is negative an arbitrage strategy would involve buying the bond and the CDS together with the same maturity. 
In this way, credit risk is hedged and the basis, i.e. non default component, is earned. This arbitrage strategy is feasible when the bond market is liquid. When the basis is positive, the arbitrage strategy would sell the CDS protection and short sell the corresponding bond. As argued in Duffie (1999) and Duffie et al. (2002b) and Nashikkar and Subrahmanyam, Mahanti (2007), shorting a bond is costly because it is difficult to find it in the securities borrowing and lending market. If the bond is illiquid, then shorting that bond will be even more costly.

\subsection{Pricing of Risky and Risk-free Bonds and Extracting the Probability of Default}

The price of a defaultable bond today $\mathrm{P}_{0}$ is obtained as the sum of (risk-neutral) expected discounted cash flows. ${ }^{7}$

$$
P_{0}=E_{0}\left[\sum_{t=1}^{T} \frac{C F_{t}}{\left(1+r_{t}\right)^{t}}\right]
$$

If the bond defaults at time $\tau<T$, the following cash-flows are zero, i. e CFi $=0, \mathrm{i} \geq \tau$.

When valuing a risk-free bond, one does not need the expectation operator, since the cash flows are certain. The price of a risk-free bond $B_{0}$ is then given:

$$
B_{0}=\sum_{t=1}^{T} \frac{C F_{t}}{\left(1+r_{t}\right)^{t}}
$$

Note that, the difference between the prices of a risk-free bond and a risky bond, both having the same promising cash flows, is equal to the discounted expected loss from holding the risky bond. Therefore we can generalize this relationship for coupon bonds as:

$$
B_{0}-P_{0}=\sum_{\tau} \frac{P D_{\tau}^{0}\left(F_{\tau}-C_{\tau} \cdot R\right)}{\left(1+r_{\tau}\right)^{\tau}}
$$

The assumptions and the properties in above formula are :

$\tau$ : $\quad$ Default is assumed to occur at coupon dates, which are semiannually in US dollar denominated emerging market bonds.

$P_{0}: \quad \quad$ Is the observed market price of the emerging market bond.

\footnotetext{
${ }^{7}$ In this analysis, the probability of default estimation and CDS valuation follow the risk-neutral valuation approach discussed in Hull, J and White, A., 2001
} 
$B_{0}$ : $\quad$ The price of the risk-free bond with the same cash flows as the risky bond. It is found by discounting the cash flows of risky bond by the risk-free spot rate implied by Libor swap rates.

$P D_{\tau}^{0}$ : $\quad$ Is the risk-neutral probability of default as seen from time 0. In my analysis I assume the probability of default is step wise constant.

$F_{\tau}$ : This is the price of the risk-free bond that is expected to prevail at date $\tau$. It is found by using the implied forward rates.

$C_{\tau}: \quad \quad$ It is the claim that a bondholder has in case of a default.

$R: \quad \quad \mathrm{R}$ is known as the recovery rate. It is the percentage of the claim that bondholders receive in case of a default.

$r$ : $\quad r$ represents the spot rates used to discount the cash flows. In this paper, Libor swap rates are used as risk-free spot rates.

Note that in equation (3), $F_{\tau}$ is the forward price of the riskless bond. Then,

$\frac{F_{\tau}}{\left(1+r_{\tau}\right)^{\tau}}$ is simply the forward price of a riskless bond discounted by risk-free rate. A discounted forward price from time $\tau$ is nothing but today's present value of the payments from time $\tau$ onwards. Then, we can rewrite (3) as:

$$
B_{0}-P_{0}=\sum_{\tau} P D_{\tau}^{0}\left(B_{o}^{\tau}-\frac{C_{\tau} R}{\left(1+r_{\tau}\right)^{\tau}}\right)
$$

where $B_{o}^{\tau}$ is the price of the riskless bond at time $\tau$ discounted to today's value. Finally, we can solve for PD assuming it is step-wise constant.

\subsection{The Hypothetical CDS Premium Implied by the Probability of Default and Maturity of a Risky Bond:}

In a CDS contract, the protection buyer pays a fee in regular intervals until the contract expires or a credit event occurs. Upon a default, the protection buyer receives the difference between the face value and the recovery value of the defaulted bonds.

$\mathrm{T}$ is the life of the CDS contract. $\mathrm{T}$ is taken as the life of the corresponding risky bond, from which the probability of default, PD, is extracted. If $\mathrm{p}$ denotes the annual CDS fee percentage paid to the protection seller, then the expected fee is:

$$
E[f e e]=F \cdot \frac{p}{f} \cdot \sum_{\tau}\left[\frac{1-\sum_{t=1}^{\tau-1} P D_{t}^{0}}{\left(1+r_{\tau}\right)^{\tau}}\right]
$$


The expected gain of the protection buyer is then:

$$
E[\text { gain }]=F \cdot \sum_{\tau}(1-R-A(\tau) R) \frac{P D_{\tau}^{0}}{\left(1+r_{\tau}\right)^{\tau}}
$$

Where, $A(t)$ is the accrued interest as a percentage of the notional principal, $F$ is the face value of the reference bond and $f$ is the frequency of premium payment in a year..

Therefore in a CDS contract, by no-arbitrage argument, one would expect $\mathrm{p}$, the CDS premium, to be such that expected gains from buying the protection is equal to expected fees paid for the protection. Equating (5) and (6) we get:

Par-equivalent CDS premium $=p^{*}=\frac{\sum_{\tau}(1-R-A(\tau) \cdot R) \cdot \frac{P D_{\tau}^{0}}{\left(1+r_{\tau}\right)^{\tau}}}{\frac{1}{f} \cdot \sum_{\tau}\left[\frac{1-\sum_{t=1}^{\tau-1} P D_{t}^{0}}{\left(1+r_{\tau}\right)^{\tau}}\right]}$

$p$ is then the hypothetical T year CDS contract implied by the probability of a default of the corresponding emerging market sovereign US dollar denominated straight, fixed coupon bond maturing exactly in $\mathrm{T}$ years.

Finally, the CDS-bond basis is defined by the difference between the actual CDS premium and the above hypothetical CDS spread where their life equals the remaining maturity of the underlying bond.

$$
\text { Basis }_{i}=C D S_{\text {Actual }, i}-C D S_{\text {Hypothetical }, i}
$$

where $i \in(0,10]$ is the maturity of the corresponding bond. $C D S_{\text {Actual, } i}$ is the market premium of a CDS contract with a maturity of $i$ years. $C D S_{\text {Hypothetical, } i}$ is the implied par-equivalent CDS premium, which is computed by extracting the default probabilities from a bond maturing in $i$ years.

Figure 2 is presented as an illustration of the calculated hypothetical par-equivalent CDS premium and resulting basis for one of Mexico's international bonds issued in 2003 and maturing in 2014.

\subsection{Distribution of CDS-Par equivalent bond yield Basis and Bond Specific Variables}

Figure 3 is presented to give our audience a flavor of the distribution of the CDS-bond basis. As seen from the first histogram, the basis distribution in the overall sample has a positive mean and is right-skewed. This right skewness comes from the speculative grade bond side. The histogram 
for the speculative bond basis shows a high degree of right skewness. In other words, the basis tends to be positive for the bonds issued by speculative grade emerging markets. On the other hand, for the investment grade sample, the distribution is more symmetric and even skewed a little bit to the left, causing a negative mean of the basis.

These results suggest that the bonds of speculative grade emerging sovereigns are more expensive relative to their CDS contracts. However on the investment grade emerging markets side, the bond prices and the CDS premiums are more balanced, and in some cases CDS premiums are cheaper relative to their bonds. The situation for speculative grade emerging markets brings arbitrage opportunities to mind. An arbitrage strategy for positive basis would involve selling the CDS contract and short selling the bond. Shorting emerging market bonds is costly. Moreover, the cost is likely to peak just prior to default, since the demand from those who intend to deliver the bonds to the protection seller would exceed the supply. It is important to note that speculative grade sovereign issuers carry a very significant amount of credit risk. Therefore, arbitrage of the positive basis of bonds by speculative grade sovereigns carries much friction, which justifies the right skewness of the basis distribution for speculative grade issuers.

Another reason for a large positive basis in the speculative grade bonds might be the speculative buys on CDSs written on bad credit quality bonds. When the news about a sovereign is bad, speculators, without owning the underlying bond, might speculate on the just by buying the CDS contract and waiting. The speculation could be either by betting on the occurrence of a credit event such as default or widening of the CDS premium. In either case, if the credit quality of the underlying worsens, the speculator would lock in a positive profit. The excess demand to CDSs would increase the CDS premium while bond prices do not fall as much as the speculation is not directly related to the risk premium of the underlying.

The above frictions are expected to be smaller in size and number for the investment grade emerging bond market. My results in Figure 3 for investment grade bonds support this hypothesis. It is seen that the mean of the basis is negative for investment grade bonds, meaning their bonds are cheaper relative to their credit risk implied by CDS contracts. Due to absence of short-sale constraints and its unfunded nature, the CDS market is thought to be more liquid compared to the bond market. Therefore it is natural to think of liquidity premiums included in the prices of investment grade bonds, which would cause bond yield spreads to be higher relative 
to CDS premiums, resulting in a negative basis. This main hypothesis is analyzed in the following sections.

The distribution of bond characteristics is presented in Figure 4. One would find the distribution of age, remaining maturity and issue amount of the bonds at the beginning of a regression sample period.

\subsection{Bond and Credit Default Swap Liquidity Variables}

The first bond market proxy is the average percentage bid-ask spread of the emerging market sovereign bonds. The bid-ask spread for each bond is calculated by taking the time series average of the daily bid-ask spread reported by Datastream. The second liquidity proxy is the average daily volume for the previous month. It is calculated by taking the total nominal turnover for an individual bond in the previous month and dividing it by the number of working days in the month. The third proxy is the notional amount outstanding for each bond. The amount outstanding is used to measure general availability of the bond in the market. The fourth proxy is the age of the bond. This proxy is similar to the notion of on-the-run and off-the-run bonds in Treasury markets. There is extensive evidence that on-the-run Treasury bonds are much more liquid than off-the-run Treasury bonds. If there is a similar effect in the emerging bond market, then older bonds may be less liquid than more-recently issued bonds (Longstaff et al. (2005)). The fifth proxy is the time to maturity of the bond. In the emerging market debt market there might be a high level of maturity clientele portfolio behavior, which may cause shorter maturity bonds to be more liquid. Moreover, academic literature reports that high coupon bonds tend to be more liquid than bonds with lower coupon bonds.

When the basis is negative, an arbitrage strategy involves buying the credit default swap protection and holding the bond until its maturity. However for an arbitrageur to benefit from the negative basis, CDS market liquidity is relevant as well. For hedging of a long position on a bond, the demand for bonds with higher liquidity in their CDS markets is expected to be higher. Therefore, one should also take into consideration the CDS market liquidity. In order to analyse

this issue, I include the daily CDS bid-ask spread and the daily percentage CDS bid-ask spread to its mid-value as proxies for the liquidity in the CDS market, and relate these variables to the CDS-bond basis. 


\section{$5 \quad$ Results}

\subsection{Correlations among liquidity variables:}

To check the consistency of the liquidity variables, Table 4 presents the correlations between bond and CDS market liquidity variables. The theory on liquidity suggests that while bond liquidity is negatively associated to bid-ask spread and the bond's age, it is positively correlated to the turnover rate, coupon rate and issue amount.

My findings suggest a negative correlation between bid-ask percentage and turnover rate, issue amount and coupon rate for all the rating groups. These results are consistent with the literature on bond liquidity.

The correlation between bond market liquidity and CDS market liquidity is also examined. If we assume that increasing bid-ask spread and/or bid-ask percentage spread in CDS market represents its illiquidity, the signs of the correlation coefficients in Table 4 would allow for the existence a positive relationship between CDS and bond market liquidity.

\subsection{Determinants of Bond Illiquidity:}

In Table 5, I present results of the panel regressions of the bond price bid-ask percentage on various bond liquidity variables, CDS market liquidity and world macroeconomic variables. The purpose of these regressions is to analyze the determinants of bond illiquidity in different rating groups assuming bid-ask percentage spread and turnover by volume capture bond liquidity to a significant extend.

Regressions of bid-ask spread on bond specific liquidity variables alone, such as turnover rate, coupon rate, bond life and bond age show expected results most of the time. Including CDS liquidity variables in the regressions, one can see a positive relationship between CDS and bond market illiquidity in all the samples. In speculative grade emerging markets, when the CDS market is illiquid, i.e. the CDS bid-ask spread is large, the bond market is also illiquid. This result is consistent with the perspective of the investors who, in search of hedging the credit risk of their long positions on the bond, buy the CDS contracts written on the same bond. When the credit risk is high, as in speculative grade bonds, this relationship is expected to hold strongly, as my results suggest. The possible spill-over effects from the CDS market to the bond market are analyzed in the following sections. 
Regressions also search for the effects worldwide macroeconomic variables such as US 6month T-bill and US term spreads between 6-month and 10-year T-bill yields on bond illiquidity. My results indicate that an increase in the 6-month T-bill rate or term spread is associated with an increase in the illiquidity of the bond markets. This can be either because an increase in the US treasury yields reduces the demand for emerging market bonds, or because the world economy gets hit by a negative shock, which may increase instability in the emerging market economies.

\subsection{Determinants of CDS-Bond Basis:}

In order to asses the determinants of the CDS-bond basis, I use unbalanced panel regressions of the CDS-bond basis on various bond market liquidity variables, CDS market liquidity variables, corresponding issuer equity market indices and worldwide macroeconomic variables. Thirty-day averages of variables are taken to run this pooled regression. Regressions are run for three different rating groups in order to analyze possible differences between different credit risk groups. Data for bond, CDS, equity market and world macroeconomic indicators collected from Datastream allow me to reach a sample size of, at most, 90,000 data points for each variable.

As discussed in Petersen (2008), in the financial data sets the residuals may be correlated across firms or across time, and OLS standard errors can be biased. Petersen (2008) shows that the standard errors clustered by firm are unbiased and produce correctly-sized confidence intervals independently on the firm effect to be permanent or temporary. Extending the literature on corporate finance data to emerging bond market data, I cluster the standard errors by each bond. Therefore, I assume the standard errors are correlated among each bond group.

\subsubsection{Emerging Market Bond Liquidity}

To check the individual effects of each bond liquidity variable on the CDS-par equivalent bond basis, I first run univariate regressions for different rating groups. Since the CDS market is expected to be more liquid compared to the bond market, one would expect the bond prices to bear a liquidity premium. My hypothesis is that the liquid bonds of investment grade emerging markets should be more expensive in the cross section, which would be indicated by a positive relationship between the CDS-bond basis and liquidity. As mentioned in section 3.2, the 
relationship between liquidity and the basis might even be inverse for speculative bonds, i.e. illiquid bonds of speculative grade emerging markets might be more expensive.

Consistent with the above hypothesis, the bid-ask spread, turnover by volume and coupon variables have the expected signs, and their magnitudes are significant for investment grade and pooled samples. For speculative grade bonds however, the bid-ask percentage variable has a positive sign and is statistically significant at a 95\% significance level, which signals a positive impact of bond illiquidity on risky bond prices.

In Table 7, the first column of regressions presents the results of the panel regressions of the monthly average CDS-bond basis to monthly averages of bond price bid-ask spreads, bond turnover rates by volume and other bond specific liquidity variables. As mentioned in the previous section, t-statistics are robust t-statistics with standard errors clustered by each bond.

I find a significant correlation between almost all bond market liquidity variables and investment grade emerging market bonds. All the variables except bond issue size have the expected signs. Results show that bond bid-ask spread, bond age and ratings have negative impact on basis. As argued before, bond age and bid-ask spreads are associated with illiquidity in the bond market. As the bond market becomes more illiquid, i.e. an increase in the bid-ask spread, one would expect the liquidity premium to be included in the emerging market bond yields, which would increase the bond yields and reduce the CDS-bond basis. My results show that a one percent increase in the bond bid-ask spread decreases the basis by fourteen basis points, which shows that the bid-ask spread variable is economically significant as well.

Since turnover rate by volume and coupon rate are expected to positively affect bond market liquidity, their signs are expected to be the opposite of bid-ask spread and bond age. This is in fact the case. My results show that the non-default component, i.e. the basis, of the liquid investment grade bonds tend to be smaller; in other words, ceteris paribus, liquid bonds tend to be more expensive in the cross section.

Unlike the corporate debt market, emerging market sovereign debt relies mostly on debt issued in the form of bonds. Countries with high debt need to acquire more debt by issuing larger bonds. So, the issue size of the bonds might have misleading results for our purposes. While bonds may become more liquid as the issue size increases, the credit quality may decrease at the same time, which would explain why the issue size variable has a negative sign. 
The effect of the bond market liquidity of speculative grade emerging markets on the nondefault component of their yield spreads is ambiguous. The bid-ask spread, turnover by volume and issue amount variables have contradictory signs and insignificant t-statistics. Liquidity of speculative grade emerging market countries does not have much correspondence to the nondefault component of the yield spreads. Moreover the signs of the variables suggest that illiquidity (liquidity) in the bond market increases (decreases) the basis, which would mean that illiquid bonds of speculative grade emerging market countries might be more expensive relative to their liquid counterparts. In a CDS contract in the case of a credit event, the protection buyer has to provide the underlying bond to the protection seller to get the face value of the bond. When the bond market is illiquid, in the case of a default it might be difficult to find the underlying bond in the market to provide to the CDS seller. This could explain why when credit quality is low (speculative grade bonds), illiquid bonds might become more expensive.

The results on remaining maturity are consistent with the previous studies suggesting that a large fraction of yield spreads, especially at the long end of the maturity range, cannot be solely explained by credit risk (Longstaff et al. (2005)).

Table 10 shows the results of unbalanced panel regressions of the par-equivalent basis on various bond liquidity variables, MSCI equity market indices and ratings controlling for country fixed effects. As can be seen from the table, the results show the impact of bond liquidity on the CDS-bond basis is robust for country fixed effects.

\subsubsection{Emerging Market CDS Market Liquidity}

The results in the Table 7 report that liquidity in the CDS market has significant effects on the non-default component over the bond liquidity variables. A one basis point increase in the CDS bid-ask spread leads to a increase in basis of 1 basis points in the overall pooled bonds, two basis points in the investment grade bond basis and one basis point in the speculative grade bonds. In other words, if one assumes level bid-ask spread as a proxy for CDS market illiquidity, bonds with higher illiquidity in their CDS market are more expensive in the cross section.

The above result might stem from two reasons (Nashikkar and Subrahmanyam and Mahanti (2007)). First, less liquidity in the CDS market is likely to drive investors towards the bond market, causing the bonds prices to increase. The correlations between the turnover by volume and CDS bid-ask spreads in Table 4 provides some counter support for this explanation. One might note the negative correlation between CDS bid-ask spread and turnover by volume. This 
means that when CDS illiquidity is high, the trade volume is low, which is the opposite of the above explanation. The second explanation states that episodes of illiquidity in the CDS market are often associated to negative news about the issuers on whom the CDS contracts are traded. It is generally difficult to short bonds, which leads to bonds becoming more expensive relative to their CDS contracts especially during the illiquid periods in the market.

The CDS bid-ask as a percentage has also positive sign and it is significant for speculative grade bonds and in pooled bonds. For investment grade bonds however the sign is negative. Assuming a percentage bid-ask spread as a proxy for illiquidity, the investment grade bonds with liquid CDS market have higher prices in the cross section. The problem of whether assuming bid-ask spread or bid-ask percentage spread as representing illiquidity in the CDS market is not easy. Both measures are subject to be affected by the level of the CDS premium. Taking the ratio of the bid-ask spread might reduce the explanatory power of the bid-ask spread variable. On the other hand there is a high correlation between CDS premium and CDS bid-ask spread, which makes level bid-ask spread a biased proxy for illiquidity in the CDS market. The interesting fact here is that, CDS liquidity variables have significant effects on the non-default component of bond yield spreads even when bond market variables are in the regression. This provides evidence of a liquidity spill-over effects from the CDS market into the bond market (Nashikkar and Subrahmanyam and Mahanti (2007)).

\subsubsection{Equity Markets}

In addition to bond market and CDS market liquidity, equity market performance of emerging markets has explanatory power for the non-default component of bond yields. The effect of equity markets has not been documented in this literature before. In order to analyse the possible effects of equity markets on bond yields, the MSCI index is used. The MSCI index was created by Morgan Stanley Capital International (MSCI) to measure equity market performance in global emerging markets.

As Table 8 shows, the MSCI index for each country's equity market has explanatory power over bond liquidity variables. According to my regression results, equity market performance has a negative impact on the non-default component. One reason for this would be equity market performance might be negatively correlated with an emerging market sovereign's credit risk. In other words, as the MSCI index increases, the credit risk and associated CDS premium should go down, which would reduce the basis (note that $\mathrm{CDS}$-bond Basis $=\mathrm{CDS}_{\text {actual- }} \mathrm{CDS}_{\text {implied }}$ ). In order 
to eliminate this possibility I include actual CDS premiums in the regression. Even though the robust t-statistics decrease, the MSCI index variable still has a significant and negative impact on the basis for overall sample and speculative bonds, while on investment grade bonds the same negative effect has no significance. The explanation for this result is in line with the findings of Blanco et al. (2005) and Zhu, H. (2006) where the authors analyze the co-integration relationship between bond yields and CDS premiums. They find that in the short run, the CDS market leads the corporate bond market in the price discovery process. Zhu, H. (2006) further argues that the short run deviation in is largely due to different responses of the two markets to changes in credit conditions. Since the equity market is more volatile in the short run, it is possible that CDS premiums internalize these equity market movements in its price earlier than the bond market; as a result, high equity market performance decreases both CDS premiums and their basis before the bond market reacts. I leave this lead-lag relationship for CDS and bond markets for future study.

Table 10 shows the results of unbalanced panel regressions of the par-equivalent basis on various bond liquidity variables, MSCI equity market indices and ratings, controlling for country fixed effects. As seen from the table, the results of the impact of equity market performances on the CDS-bond basis are robust for country fixed effects.

\subsubsection{Effects of World-wide Macroeconomic Conditions}

It has been shown that the credit risk on sovereigns depends highly on the world's macroeconomic conditions. For instance, Longstaff et al.(2007) argue that sovereign credit spreads are generally more related to the U.S. stock and high-yield bond markets, global risk premia, and capital flows than they are to their own local economic measures. Moreover they state that a significant amount of the variation in sovereign credit returns can be used to forecast using U.S. equity, volatility, and bond market risk premia.

I control for the credit risk of the sovereigns, to check whether macroeconomic conditions affect the yields only through the credit risk channel. I included the CDS premiums of the sovereigns in the regression to control explicitly for the credit risk and see whether world macroeconomic conditions have explanatory power over and above the credit risk of the sovereigns. As seen in Table 9, while the 6-month T-bill rate and the US term spread keep their significance, the S\&P500 return index and its volatility lose their significance for investment grade and pooled samples. On the speculative grade bond sample, the significance of the 
variables decrease but do not vanish when I include the CDS premiums. So, even if it is true that world macroeconomic conditions affect speculative grade emerging market bond yield spreads through the non-default component, the effects seem to be through the contingent credit risk channel for investment grade bonds, non-default components seem to not be affected by macroeconomic variables to a great extent.

\subsubsection{Credit Risk and CDS-Bond Basis:}

The impact of credit quality proxied by ratings is analyzed in Table 7 and Figure 3. Table 7 , which reports the regressions of the CDS-bond basis on various liquidity variables and ratings, shows that ratings have a negative and significant impact on the CDS-bond basis. As ratings escalate from B1 to Aaa, the CDS-bond basis declines. Moreover, as presented in section 3.2, the average basis for investment grade bonds, i.e. ratings equal to or higher than Baa, is negative.

The hypothesis is that liquidity and the cost of short selling have important impacts on the CDS-bond basis. When short selling is feasible, one would expect higher liquidity is associated with higher bond prices, thus the higher basis. However, the opposite can be the case under high short selling costs. The results in Figure 3 and Table 7 together suggest the following. First, the average basis is positive for speculative grade bonds, and negative for investment grade bonds. Second, as ratings increase the basis decreases and becomes negative for investment bonds. So, as credit risk increases, the CDS-bond basis increases, making the bonds more expensive relative to what would be implied by their CDS contracts. An arbitrage strategy for the positive basis would involve selling the CDS contract and short selling the bond. Shorting emerging market bonds is costly and this cost is likely to peak just prior to default, since the demand from those who intend to deliver the bonds to the protection seller would exceed the supply. Since speculative grade sovereigns carry a very significant amount of credit risk, positive basis arbitrage might be unfeasible.

Therefore, the illiquid bonds of highly risky sovereigns might be more expensive relative to their liquid counterparts. In Table 7, illiquidity captured by bid-ask spread has a positive sign on the basis, and turnover by volume has a negative sign with insignificant t-statistics. These results for speculative grade bonds in Table 7 justify the hypothesis that with a considerable deterioration of credit quality the illiquid bonds may become more expensive.

The above effects of friction in the investment grade emerging bond market are expected to be smaller since short selling is easier with higher credit quality and liquidity. Due to the absence of 
short-sale constraints and its unfunded nature, the CDS market is thought of being more liquid compared to the bond market. Therefore, it is natural to think of liquidity premiums included in the prices of bonds of investment grade bonds, which would force bond yield spreads to be higher relative to CDS premiums and cause a negative basis. This main hypothesis is justified by the results in Figure 3 and Table 7. First, the mean of the basis is negative for investment grade bonds; in other words, bond prices carry a liquidity premium and they are relatively cheaper compared to what is implied by their CDS premiums. Second, as ratings increase, the average CDS-bond basis decreases. Third, liquidity has a positive and significant impact on the basis for investment grade sovereign bonds and this effect carries through to the non-default component.

\section{Conclusion}

In this research, I estimate the non-default component of emerging market bond yields and analyze the relationship between the non-default components of yield spreads with liquidity. I calculate the CDS-bond basis, which is the difference between the actual CDS premium of a bond and its hypothetical par equivalent CDS premium, as a measure of the non-default component, allowing for a non-flat credit curve term structure. I exploit nearly all available straight-fixed rate emerging market bonds denominated in US dollars between January 2004 and May 2008, which amount to 107 bonds. The data from Datastream allows me to use bid-ask spread and turnover by volume as my main liquidity variables. Moreover, I include coupon rate, remaining maturity, age, and issue amount as liquidity-related variables in my empirical analysis.

My results show that while the basis is mainly positive for speculative grade, it is negative for investment grade bonds. In other words, the bonds of speculative grade emerging sovereigns are more expensive then what is implied by their CDS premiums. For investment grade, bond prices and CDS premiums are more balanced, and CDS premiums may even be cheaper relative to their bonds. So, CDS premiums of investment grade bonds imply higher prices for their existing bonds. The positive basis for speculative grade bonds is justified by the difficulty of arbitrage. It is difficult to arbitrage away the positive basis in a market with friction caused by short selling costs, which peaks with the increase of credit risk. Another reason for a large positive basis in the speculative grade bonds might be the speculative buys on CDSs written on bad credit quality bonds. When the news about a sovereign is bad, speculators, without owning the underlying 
bond, might speculate on worsening of the credit conditions of the underlying just by buying the CDS contract. This speculation could be either by betting on the occurrence of a credit event or widening of the CDS premium. The excess demand to CDSs would increase the CDS premium while bond prices do not fall as much since the speculation is not directly related to the risk premium of the underlying.

On the other hand, there are fewer frictional elements in the investment grade bond market. The fact that the non-default components of investment grade bond yields are negative gives us a clue that bond prices might include liquidity premiums, since the CDS market is expected to be more liquid than the bond market due to the absence of short-sale constraints and its unfunded nature ,

I find significant the power of liquidity in explaining the non-default components of investment grade emerging market bonds. However, the effects of liquidity on speculative grade emerging market bonds are ambiguous or contrary to what I find for the investment grade bonds. These results are in line with my initial hypothesis that investment grade emerging market bond prices include liquidity premiums. On the other hand, I expect normal shorting costs, peaking with worsening credit conditions, might render the illiquid bonds of risky speculative emerging market bonds more expensive. My results also confirm this hypothesis; liquidity has counter effects on non-default components with increasing credit risk.

As a novelty to this literature, I report that the domestic stock market performance of emerging markets has a significant negative impact on the non-default component of bond yields. The reason for the negative sign seems to be related to the credit risk and lead-lag relationship between the CDS and bond markets.

CDS liquidity measured as bid-ask spread and percentage bid-ask spread also has explanatory power for the basis over the bond liquidity variables. Since higher liquidity in the CDS market would mean easier hedging of a long position on a bond, it is natural to think of bond market participants taking CDS liquidity into account when pricing the emerging market bonds.

Another contribution to the literature is to explain whether the world macroeconomic conditions affect the emerging market bond yields solely through credit risk or through their nondefault components. Depending on the results, without explicitly controlling for credit risk, one can say that good short term macroeconomic conditions have a negative effect on the basis. In other words, better macroeconomic conditions may cause bonds to become cheaper than what is 
implied by their CDS contracts. After explicitly controlling for credit risk, while the significance of the variables decrease but do not vanish for speculative grade bonds, the variables become insignificant for investment grade bonds. So, even if it is true that world macroeconomic conditions affect speculative grade emerging market bond yield spreads through the non-default component, the effects seem to be through the contingent credit risk channel for investment grade bonds; non-default components seem to not be affected by macroeconomic variables to a great extent.

To summarize, this paper is a first attempt to isolate the non-default component of emerging market bond yield spreads and relate it with liquidity. Thanks to availability of reliable transaction data in bond and CDS markets, I aim to offer some interesting and novel results on emerging market bond yields and on CDS market, liquidity, and stock market performances. 


\section{Bibliography}

Acharya, V. V., \& Pedersen, L. H. (2005). Asset pricing with liquidity risk. Journal of Financial Economics , 175-410.

Alexander, G., Edwards, A., \& Ferri, M. (2004). The determinants of trading volume of highyield corporate bonds. Journal of Financial Markets , 177-204.

Amihud, Y. (2002). Illiquididy and stock returns: Cross-section and time-series effects. Journal of Financial Markets , 31-56.

Amihud, Y., \& Mendelson, H. (1986). Asset pricing and bid-ask spreads. Journal of Financial Economics , 223-249.

Ammer, J., \& Cai, F. (2007). Sovereign CDS and bond pricing dynamics in emerging markets: Does the cheapest-to-deliver option matter? FRB International Finance Discussion Paper.

Blanco, R., Brennan, S., \& March, I. (2005). An empirical analysis of the dynamic relationship between investment-grade bonds and credit default swaps. Journal of Finance , 60, 2255-2281.

Chakravarty, S., \& Sarkar, A. (2003). Trading costs in three US bond markets. Journal of Fixed Income , 39-48.

Chen, L., Lesmond, D., \& Wei, J. (2007). Corporate yield spreads and bond illiquidity. Journal of Finance , 119-149.

Collin-Dufresne, P., Goldstein, R., \& Spencer, M. (2001). The determinants of credit spread changes. Journal of Finance , 56, 2177-2207.

Deliandeis, G., \& Geske, R. (2001). The components of corporate credit spreads: Default, recovery, tax, jumps, liquidity and marcet factors. UCLA .

Duffee, G. (1999). Estimationg the price of default risk. Review of Financial Studies , 12, 197 226.

Duffee, G. (1996). Idiosyncratic variations in treasury bill yields. Journal of Finance , 51, 527551.

Duffie, D. (1999). Credit swap valuation. Financial Analysts Journal , 73-87.

Duffie, D., \& Liu, J. (2001). Floating-fixed credit spreads. Financial Analyst Journal , 76-87.

Edwards, A., Harris, L., \& Piwowar, M. (2007). Corporate bond market transaction costs and transparency. Journal of Finance , 62, 1421-1431. 
Elton, E., Gruber, M., Mann, A., \& Mann, C. (2001). Explaining the rate spread on corporate bonds. Journal of Finance , 56, 247-277.

Eom, Y. H., Helwege, J., \& Huang, J. (2004). Structural models of corporate bond pricing: an empirical analysis. Review of Financial Studies , 17, 499-544.

Ericsson, J., \& Renault, O. (2006). Liquidity and credit risk. Journal of Finance , 61, 2219-2250.

Ericsson, J., Reneby, J., \& Wang, H. (2007). Can structural models price default risk? Evidence from bond and credit derivative markets. McGill University Working Paper.

Fisher, L. (1956). Determinants of the risk premiums on corporate bonds. Journal of Political Economy, 67, 217-237.

Fleming, M. J. (2003). Measuring treasury market liquidity. Federal Reserve Bank of New York Economic Policy Review , 9, 83-108.

Han, S., \& Zhou, H. (2008). Effects of Liquidity on the Nondefault Component of Corporate Yield Spreads: Evidence from Intraday Transactions Data. Federal Reserve Discussion Working Paper.

Hong, G., \& Warga, A. (2000). An empirical study of corporate bond market. Financial Analyst Journal , 56, 32-46.

Hotchkiss, E., \& Jostiva, G. (n.d.). Determinants of corporate bond trading: A comprehensive analysis. Boston College Working Paper .

Hotchkiss, E., \& Ronen, T. (2002). The informational efficiency of the corporate bond market: an intraday analysis. Review of Financial Studies , 15, 1325-1354.

Houweling, P., \& Vorst, T. (2005). Pricing default swaps: Empirical evidence. Journal of International Money and Finance , 24, 1200-1225.

Houweling, P., Mentink, A., \& Vorst, T. (2005). Comparing possible proxies of corporate bond liquidity. Journal of Banking and Finance , 29, 1331-1358.

Huang, J., \& Zhou, H. (2007). Specification analysis of structural credit risk models. Pennsylvania State University Working Paper.

Hull, J., \& White, A. (2001). Valuing Credit Default Swaps I: No counterparty risk' Journal of Derivatives. Journal of Derivatives , 8, 29-40.

Hull, J., Predescu, M., \& White, A. (2004). The relationship between credit default swap spreads, bond yields, and credit rating announcements. Journal of Banking and Finance , 28, 2789-2811. 
Hund, J., \& Lesmond, D. (2006). Liquidity and Credit Risk in Emerging Debt Markets. Working Paper.

Jones, E. P., \& Rosenfeld, E. (1984). Contingent claims analysis of corporate capital structures:An empirical investigation',. Journal of Finance , 39, 611-625.

Kyle, A. (1985). Continuous auctions and insider trading. Econometrica, 53, 1315-1335. Lando, D. (2004). Credit risk modeling. Theory and applications. Princeton University Press.

Liu, J., A., L. F., \& Mandell, R. (2006). The market price of risk in interestrate swaps: The roles of default and liquidity risks. Journal of Business , 79(5), 2337-59.

Lo, A. W., Mamaysky, H., \& Wang, J. (2004). Asset prices and trading volume under fixed transactions costs. Journal of Political Economy , 112, 1054-1090.

Loffler, G., \& Peter, P. (2007). Credit Risk Modeling Using Excel and VBA. Wiley Finance. Longstaff, F. A. (2004). The flight-to-liquidity premium in u.s. treasury bond prices. Journal of Business , 77, 511-526.

Longstaff, F. A., Mithal, S., \& Neis, E. (2005). Corporate yield spreads: Default risk or liquidity? new evidence from the credit default swap market. Journal of Finance , 60, 2213-53.

Longstaff, F., \& Schwartz, E. (1995). A simple approach to valuing risky fixed and floating rate debt. Journal of Finance , 50, 789-820.

Longstaff, F., Pan, J., Pedersen, L., \& Singleton, K. (2006). How sovereign is sovereign credit risk? NBER Working Paper.

Nashikkar, A., \& Subrahmanyam, M. (2007). Latent liquidity and corporate bond yield spreads. School of Business, New York University. Working Paper .

Norden, L., \& Weber, M. (2004). The comovement of credit default swap, bond and stock markets: an empirical analysis. Working paper. University of Mannheim, Germany .

Petersen, M. (2008). Estimating standard errors in finance panel data sets: comparing approaches. The Review of Financial Studies .

Roll, R. (1984). A simple implicit measure of the effective bid-ask spread in an efficient market. Journal of Finance .

Schultz, P. (2001). Corporate bond trading costs: A peek behind the curtain. Journal of Finance, 56, 677-698.

Tang, D., \& Hong, Y. (2007). Liquidity and credit default swap spreads. University of South Carolina Working Paper. 
Vayanos, D. (1998). Transaction costs and asset prices: A dynamic equilibrium model',. Review of Financial Studies , 11, 1-58.

Zhu, H. (2006). An empirical comparison of credit spreads between the bond market and the credit default swap market. Journal of Financial Services Research , 29(3), 211-35. 


\section{Tables and Figures}

\begin{tabular}{|c|c|c|}
\hline \multicolumn{3}{|c|}{ Emerging Countries, Ratings and Number of Bonds } \\
\hline & Moody`s Rating & \# of Bonds \\
\hline Brazil & $\mathrm{Ba} 1$ & 12 \\
\hline Chile & $\mathrm{A} 2$ & 3 \\
\hline China & A1 & 5 \\
\hline Colombia & $\mathrm{Ba} 2$ & 10 \\
\hline Egypt & Ba1 & 2 \\
\hline Korea & $\mathrm{A} 2$ & 4 \\
\hline Lebanon & B3 & 6 \\
\hline Malaysia & $\mathrm{A} 3$ & 4 \\
\hline Mexico & Baa1 & 9 \\
\hline Pakistan & B2 & 3 \\
\hline Panama & Ba1 & 2 \\
\hline Peru & $\mathrm{Ba} 2$ & 5 \\
\hline Philippines & B1 & 5 \\
\hline Poland & $\mathrm{A} 2$ & 5 \\
\hline Qatar & $\mathrm{Aa} 2$ & 4 \\
\hline Russia & Baa2 & 3 \\
\hline South Africa & Baa1 & 4 \\
\hline Thailand & Baa1 & 1 \\
\hline Turkey & $\mathrm{Ba} 3$ & 9 \\
\hline Ukraine & B1 & 4 \\
\hline Venezuela & $\mathrm{B} 2$ & 7 \\
\hline
\end{tabular}

Table 1: This table shows emerging market countries, their Long term liability ratings assigned by Moody's and number of fixed-rate international US dollar denominated bonds included in the paper.

The bonds in the sample are straight maturity and have fix coupon rates.

Bond prices and yield to maturities are calculated again to check the correctness of the data. Among our sample of bonds, nearly $90 \%$ of them have bid-ask spreads, and $97 \%$ have either bid-ask spreads or turnover by volume data available.

This data availability allows me to use direct liquidity proxies of bid-ask spreads and turnover ratios. All bond data is collected from Datastream and double checked by comparing the data from Bloomberg terminals. 


\begin{tabular}{|c|c|c|c|}
\hline \multicolumn{4}{|c|}{ Distribution of Emerging Market Bonds by Moody`s Credit Rating } \\
\hline & $\begin{array}{l}\text { Number of } \\
\text { Countries }\end{array}$ & $\begin{array}{l}\text { Number of } \\
\text { Bonds }\end{array}$ & $\begin{array}{l}\text { Regression Codes } \\
\#\end{array}$ \\
\hline Aaa & 0 & 0 & 21 \\
\hline Aa1 & 0 & 0 & 20 \\
\hline $\mathrm{Aa} 2$ & 1 & 4 & 19 \\
\hline Aa3 & 0 & 0 & 18 \\
\hline A1 & 1 & 5 & 17 \\
\hline $\mathrm{A} 2$ & 2 & 12 & 16 \\
\hline A3 & 1 & 4 & 15 \\
\hline Baa1 & 3 & 14 & 14 \\
\hline Baa2 & 1 & 3 & 13 \\
\hline Baa3 & 1 & 0 & 12 \\
\hline Ba1 & 2 & 16 & 11 \\
\hline $\mathrm{Ba} 2$ & 3 & 15 & 10 \\
\hline $\mathrm{Ba} 3$ & 1 & 9 & 9 \\
\hline B1 & 2 & 9 & 8 \\
\hline B2 & 2 & 10 & 7 \\
\hline B3 & 1 & 6 & 6 \\
\hline $\begin{array}{l}\text { Investment } \\
\text { Grade }\end{array}$ & 10 & 42 & $\#>11$ \\
\hline $\begin{array}{l}\text { Speculative } \\
\text { Grade }\end{array}$ & 11 & 65 & $\#<12$ \\
\hline TOTAL & & & \\
\hline
\end{tabular}

Table 2: This table shows the distribution of United States Dollar denominated International Bonds Issued by Emerging Market Sovereigns by Moody's Long term obligation ratings.

A total of 107 US dollar denominated international bonds is issued by 21 emerging countries. The countries rated $\mathrm{Baa} 3$ and above are considered as investment grade while Ba1 and below are speculative grade. In the regression analysis, I number bonds with a B3 grade as 6 . The numbers given to bonds increased with each rating to a maximum of 21 , which corresponds to the rating Aaa. While 42 bonds are issued by investment grade emerging countries, the rest are issued by speculative grade emerging countries.

Data is collected from Datastream and its validity is double checked with the data obtained from Bloomberg. 


\begin{tabular}{llrrrr}
\hline Summary statistics & \multicolumn{6}{l}{ Min } & Max \\
\hline \hline Variable & Obs & \multicolumn{1}{c}{ Mean } & Std. Dev. & \multicolumn{1}{c}{ Min } \\
\hline CDS-Par Equivalent Basis & 85393 & 40 & 60 & -100 & 500 \\
Bid-Ask Percent & 79991 & 0.7 & 0.6 & 0.0 & 6.4 \\
Par Equivalent CDS & 85383 & 122 & 105 & -177 & 625 \\
Turnover by Volume (in millions) & 79973 & 9.1 & 0.2 & 0.0 & 340.0 \\
Amount (in millions) & 85393 & 999 & 491 & 2 & 3000 \\
Maturity (yrs) & 85393 & 6.0 & 2.6 & 0.4 & 13.2 \\
Coupon & 85393 & 8.2 & 2.4 & 2.0 & 14.5 \\
Age (yrs) & 85393 & 4.2 & 2.6 & 0.0 & 14.0 \\
CDS Bid-Ask Sprd & 85393 & 4.88 & 5.14 & 0.00 & 48.75 \\
CDS B-A Pct & 85296 & 8.5 & 23.7 & 0.4 & 415.4 \\
MSCI index & 68007 & 670 & 294 & 34 & 1742 \\
Moody`s Rating & 85393 & 11.7 & 3.6 & 6.0 & 19.0 \\
6 month US Treasury & 85329 & 3.9 & 1.3 & 1.0 & 5.3 \\
10 yr US Treasury & 85329 & 4.5 & 0.4 & 3.5 & 5.1 \\
CBOEVIX & 85329 & 15.3 & 4.5 & 10.5 & 26.4 \\
COMIX & 85329 & 370 & 69 & 265 & 547 \\
S\&P Composite Pr Index & 85329 & 1309 & 125 & 1091 & 1536 \\
\hline \hline
\end{tabular}

Table 3 : This table shows the summary statistics of the average values of the CDS-par equivalent bond basis, percentage bid ask spread of bond prices, issue amount, monthly average turnover by volume, remaining maturity in years for each bond, coupon rate, age of the bonds in years, bid-ask spread of 5year CDS premiums, 6-month and 10-year US Treasury bill rate, Chicago Board of Exchange VIX index, CRN Commodity Price Index and S\&P 500 composite price index. The MSCI index is the equity market index of the sovereigns produced by Morgan Stanley.

While Bid-Ask Percentage, CDS Bid-Ask, Computed Par-equivalent CDS premium, Treasury Bill yields, CBOVIX, COMIX and S\&P500 Composite index variables are daily, Turnover rate by volume is only available monthly.

Computation of the Par-equivalent CDS premium and CDS-Par Equivalent CDS basis is explained in the text. Turnover Ratio is the ratio of monthly average turnover to the amount of bonds available for trade. Rating variable is Moody's Long-term obligation ratings. Numbers starting from 6 are given to long term obligation ratings starting with B1 in our sample and continues to 21 , which is the highest rating, Aaa.

The CBOE Volatility Index (VIX) is a key measure of market expectations of near-term volatility conveyed by S\&P 500 stock index option prices. Since its introduction, VIX has been considered by many to be the world's premier barometer of investor sentiment and market volatility. The data is collected from DataStream 


\begin{tabular}{|c|c|c|c|c|c|c|c|c|}
\hline \multicolumn{9}{|c|}{ Correlations between liquidity related variables in the sample : Pooled Sample } \\
\hline & $\begin{array}{l}\text { Bid-Ask } \\
\text { Pct }\end{array}$ & Turnover & $\begin{array}{l}\text { Issue } \\
\text { Amt }\end{array}$ & Maturity(yrs) & Coupon & Age(yrs) & $\begin{array}{l}\text { CDS Bid- } \\
\text { Ask }\end{array}$ & CDS B-A Pct \\
\hline Bid-Ask Pct & 1.00 & & & & & & & \\
\hline Turnover & -0.20 & 1.00 & & & & & & $(\mathrm{obs}=76336)$ \\
\hline Issue Amt & -0.20 & 0.15 & 1.00 & & & & & \\
\hline $\begin{array}{l}\text { Maturity } \\
\text { (vrs) }\end{array}$ & 0.06 & 0.16 & 0.09 & 1.00 & & & & \\
\hline Coupon & -0.33 & 0.11 & -0.12 & -0.17 & 1.00 & & & \\
\hline Age (yrs) & -0.11 & -0.01 & -0.29 & -0.45 & 0.33 & 1.00 & & \\
\hline CDS Bid- & & & & & & & & \\
\hline & 0.29 & -0.10 & -0.25 & 0.16 & 0.08 & -0.28 & 1.00 & \\
\hline $\begin{array}{l}\text { CDS B-A } \\
\text { Pct }\end{array}$ & 0.01 & -0.02 & -0.01 & -0.03 & -0.01 & -0.12 & 0.01 & 1.00 \\
\hline \multicolumn{9}{|c|}{ Correlations between liquidity related variables in the sample : Investment Grade Sample } \\
\hline & $\begin{array}{l}\text { Bid- } \\
\text { Ask } \\
\text { Pct } \\
\end{array}$ & Turnover & $\begin{array}{l}\text { Issue } \\
\text { Amt }\end{array}$ & Maturity (yrs) & Coupon & $\begin{array}{l}\text { Age } \\
\text { (yrs) }\end{array}$ & $\begin{array}{l}\text { CDS Bid- } \\
\text { Ask }\end{array}$ & CDS B-A Pct \\
\hline Bid-Ask Pct & 1.00 & & & & & & & \\
\hline Turnover & -0.20 & 1.00 & & & & & & $(o b s=30713)$ \\
\hline Issue Amt & -0.15 & -0.06 & 1.00 & & & & & \\
\hline Maturity (yrs) & -0.02 & 0.09 & 0.02 & 1.00 & & & & \\
\hline Coupon & -0.65 & 0.36 & 0.00 & -0.22 & 1.00 & & & \\
\hline Age (yrs) & -0.15 & 0.17 & -0.30 & -0.58 & 0.58 & 1.00 & & \\
\hline CDS Bid-Ask & -0.12 & -0.05 & -0.25 & 0.26 & 0.10 & -0.19 & 1.00 & \\
\hline CDS B-A Pct & 0.02 & -0.25 & -0.34 & 0.09 & -0.19 & -0.18 & 0.57 & 1.00 \\
\hline \multicolumn{9}{|c|}{ Correlations between liquidity related variables in the sample: Speculative Grade Sample } \\
\hline & $\begin{array}{l}\text { Bid-Ask } \\
\text { Pct } \\
\end{array}$ & Turnover & $\begin{array}{l}\text { Issue } \\
\text { Amt } \\
\end{array}$ & Maturity (yrs) & Coupon & $\begin{array}{l}\begin{array}{l}\text { Age } \\
(\mathrm{yrs})\end{array} \\
\end{array}$ & $\begin{array}{l}\text { CDS Bid- } \\
\text { Ask }\end{array}$ & CDS B-A Pct \\
\hline Bid-Ask Pct & 1.00 & & & & & & & \\
\hline Turnover & -0.20 & 1.00 & & & & & & $(o b s=45623)$ \\
\hline Issue Amt & -0.25 & 0.53 & 1.00 & & & & & \\
\hline $\begin{array}{l}\text { Maturity } \\
\text { (yrs) }\end{array}$ & 0.13 & 0.32 & 0.16 & 1.00 & & & & \\
\hline Coupon & -0.19 & -0.16 & -0.12 & -0.27 & 1.00 & & & \\
\hline Age (yrs) & -0.05 & -0.35 & -0.33 & -0.35 & 0.46 & 1.00 & & \\
\hline CDS Bid- & & & & & & & & \\
\hline $\begin{array}{l}\text { Ask } \\
\text { CDS B-A }\end{array}$ & 0.50 & -0.16 & -0.26 & 0.14 & -0.20 & -0.28 & 1.00 & \\
\hline Pct & 0.01 & 0.03 & 0.04 & -0.05 & 0.02 & -0.14 & -0.02 & 1.00 \\
\hline
\end{tabular}

Table 4: These tables show the correlations between liquidity-related variables in the whole bond sample, investment grade bond sample, and speculative grade bond sample.

Samples have observation numbers reported in the corresponding tables. There are a total of 107 bonds issued by 21 emerging countries included in the sample. All the variables are 3-month averages of their values. While BidAsk Percentage and CDS Bid-Ask are daily, Turnover rate by volume is a monthly figure. As in the regressions, we use monthly averaged values of the variables.

Data is obtained from Datastream 


\begin{tabular}{|c|c|c|c|c|c|c|c|c|c|}
\hline \multicolumn{10}{|l|}{$\begin{array}{l}\text { Bid-Ask } \\
\text { Percent }\end{array}$} \\
\hline & \multicolumn{2}{|c|}{ All Rating Grades } & & \multicolumn{2}{|c|}{ Investment Grade } & \multicolumn{4}{|c|}{ Speculative Grade } \\
\hline & $\# 1$ & $\# 2$ & \# 3 & $\# 1$ & $\# 2$ & \# 3 & \# 1 & $\# 2$ & \# 3 \\
\hline T.over(mils) & $\begin{array}{c}-4.46 \\
(4.41)^{* *}\end{array}$ & $\begin{array}{c}-3.63 \\
(3.83)^{* *}\end{array}$ & $\begin{array}{c}-3.61 \\
(3.76)^{* *}\end{array}$ & $\begin{array}{l}1.37 \\
(1.3)\end{array}$ & $\begin{array}{c}0.72 \\
(0.73)\end{array}$ & $\begin{array}{c}0.79 \\
(0.90)\end{array}$ & $\begin{array}{c}0.00 \\
(2.8)^{* *}\end{array}$ & $\begin{array}{c}0.00 \\
(2.24)^{*}\end{array}$ & $\begin{array}{c}0.00 \\
(2.31)^{*}\end{array}$ \\
\hline Coupon & $\begin{array}{c}-0.08 \\
(2.02)^{*}\end{array}$ & $\begin{array}{l}-0.10 \\
(2.44)^{*}\end{array}$ & $\begin{array}{l}-0.10 \\
(2.43)^{*}\end{array}$ & $\begin{array}{c}-0.29 \\
(4.54)^{* *}\end{array}$ & $\begin{array}{c}-0.30 \\
(5.09)^{* *}\end{array}$ & $\begin{array}{l}-0.31 \\
(5.38)\end{array}$ & $\begin{array}{l}-0.05 \\
(1.79)\end{array}$ & $\begin{array}{l}-0.04 \\
(1.63)\end{array}$ & $\begin{array}{l}-0.06 \\
(1.41)\end{array}$ \\
\hline Mat.(yrs) & $\begin{array}{l}0.006 \\
(0.27)\end{array}$ & $\begin{array}{l}0.002 \\
(0.09)\end{array}$ & $\begin{array}{l}0.003 \\
(0.12)\end{array}$ & $\begin{array}{c}-0.010 \\
(0.29)\end{array}$ & $\begin{array}{r}-0.020 \\
(0.58)\end{array}$ & $\begin{array}{l}-0.023 \\
(0.70)\end{array}$ & $\begin{array}{l}0.035 \\
(1.35)\end{array}$ & $\begin{array}{l}0.027 \\
(0.91)\end{array}$ & $\begin{array}{l}0.031 \\
(1.12)\end{array}$ \\
\hline Age (yrs) & $\begin{array}{l}-0.017 \\
(0.61)\end{array}$ & $\begin{array}{l}0.015 \\
(0.52)\end{array}$ & $\begin{array}{l}0.015 \\
(0.53)\end{array}$ & $\begin{array}{l}0.090 \\
(2.34)^{*}\end{array}$ & $\begin{array}{c}0.094 \\
(2.23)^{*}\end{array}$ & $\begin{array}{l}0.108 \\
(2.48)\end{array}$ & $\begin{array}{l}-0.010 \\
(0.27)\end{array}$ & $\begin{array}{l}0.030 \\
(0.77)\end{array}$ & $\begin{array}{l}0.030 \\
(0.75)\end{array}$ \\
\hline Amt(mils) & $\begin{array}{c}-0.316 \\
(3.74)^{* *}\end{array}$ & $\begin{array}{l}-0.184 \\
(2.08)^{*}\end{array}$ & $\begin{array}{l}-0.182 \\
(2.05)^{*}\end{array}$ & $\begin{array}{l}-0.080 \\
(0.62)\end{array}$ & $\begin{array}{l}-0.130 \\
(0.87)\end{array}$ & $\begin{array}{l}-0.120 \\
(0.81)\end{array}$ & $\begin{array}{c}0.000 \\
(2.37)^{*}\end{array}$ & $\begin{array}{l}0.000 \\
(0.86)\end{array}$ & $\begin{array}{l}0.000 \\
(0.82)\end{array}$ \\
\hline CDS B-Ask & & $\begin{array}{c}0.018 \\
(2.96)^{* *}\end{array}$ & $\begin{array}{c}0.018 \\
(2.76)^{* *}\end{array}$ & & $\begin{array}{c}0.029 \\
(2.06)^{*}\end{array}$ & $\begin{array}{l}0.010 \\
(0.68)\end{array}$ & & $\begin{array}{c}0.019 \\
(3.70)^{* *}\end{array}$ & $\begin{array}{c}0.021 \\
(3.47)^{* *}\end{array}$ \\
\hline CDS B-A\% & & $\begin{array}{c}0.0001 \\
(0.13)\end{array}$ & $\begin{array}{c}0.0001 \\
(0.19)\end{array}$ & & $\begin{array}{l}-0.012 \\
(2.75)^{*}\end{array}$ & $\begin{array}{l}-0.009 \\
(1.88)^{*}\end{array}$ & & $\begin{array}{c}0.0004 \\
(1.31)\end{array}$ & $\begin{array}{l}0.001 \\
(1.74)\end{array}$ \\
\hline $6 \mathrm{M}$. T-bill & & & $\begin{array}{l}0.026 \\
(0.59)\end{array}$ & & & $\begin{array}{c}0.277 \\
(6.18)^{* *}\end{array}$ & & & $\begin{array}{l}-0.061 \\
(1.19)\end{array}$ \\
\hline US Term & & & $\begin{array}{l}0.015 \\
(0.19)\end{array}$ & & & $\begin{array}{c}0.450 \\
(6.02)^{* *}\end{array}$ & & & $\begin{array}{l}-0.145 \\
(1.59)\end{array}$ \\
\hline _cons & $\begin{array}{c}1.78 \\
(3.97)^{* *}\end{array}$ & $\begin{array}{c}1.49 \\
(3.06)^{* *}\end{array}$ & $\begin{array}{c}1.37 \\
(3.03) * *\end{array}$ & $\begin{array}{c}2.23 \\
(4.07)^{* * *}\end{array}$ & $\begin{array}{c}2.47 \\
(3.88)^{* *}\end{array}$ & $\begin{array}{c}1.16 \\
(1.93)\end{array}$ & $\begin{array}{c}1.34 \\
(3.50)^{* * *}\end{array}$ & $\begin{array}{c}0.75 \\
(2.21)^{* *}\end{array}$ & $\begin{array}{c}0.94 \\
(2.06) *\end{array}$ \\
\hline Obs & 76420 & 76331 & 76282 & 30714 & 30712 & 30690 & 45706 & 45619 & 45592 \\
\hline R-sqrd & 0.19 & 0.26 & 0.26 & 0.51 & 0.53 & 0.56 & 0.15 & 0.30 & 0.32 \\
\hline \multicolumn{10}{|c|}{$\begin{array}{l}* \text { significant at } 5 \% \\
* * \text { significant at } 1 \%\end{array}$} \\
\hline Robust t-sta & are in pa & ntheses & & & & & & & \\
\hline
\end{tabular}

Table 5: Pooled and Rating-Grouped Regressions of Percentage Bid Ask Spread of Bonds on Various Liquidity Related and Macroeconomic Variables.

This table shows the results of the pooled, investment grade and speculative grade bond samples of bid ask percentage variables on bond specific liquidity related variables, CDS liquidity variables and main macroeconomic variables such as 6-month and term spread between 6-months and 10-year US treasury yields. Above regressions are unbalanced panels consisting of 76420, 30714 and 45706 observations respectively. The $\mathrm{t}$-statistics reported in parentheses are robust $\mathrm{t}$-statistics with standard errors clustered by bond. Data is obtained from Datastream.. 


\begin{tabular}{|c|c|c|c|c|c|c|c|c|c|c|c|c|c|c|c|c|c|c|}
\hline \multicolumn{19}{|c|}{ CDS- bond Basis } \\
\hline \multicolumn{7}{|c|}{ All Rating Grades } & \multicolumn{6}{|c|}{ Investment Grade } & \multicolumn{6}{|c|}{ Speculative Grade } \\
\hline $\begin{array}{l}\text { Bid- } \\
\text { Ask\% }\end{array}$ & $\begin{array}{l}-6.35 \\
(0.61)\end{array}$ & & & & & & $\begin{array}{l}-29.50 \\
(6.2)^{* *}\end{array}$ & & & & & & $\begin{array}{l}13.97 \\
(2.3)^{*}\end{array}$ & & & & & \\
\hline T.ovr(ml) & & $\begin{array}{c}1.06 \\
(7.9)^{* *}\end{array}$ & & & & & & $\begin{array}{c}1.28 \\
(11.1)^{* *}\end{array}$ & & & & & & $\begin{array}{c}0.79 \\
(3.3)^{* *}\end{array}$ & & & & \\
\hline Mat.(yrs) & & & $\begin{array}{l}10.50 \\
(6)^{* *}\end{array}$ & & & & & & $\begin{array}{c}4.50 \\
(4.2)^{* *}\end{array}$ & & & & & & $\begin{array}{c}13.82 \\
(14.1)^{* *}\end{array}$ & & & \\
\hline Coupon & & & & $\begin{array}{c}10.40 \\
(6.4)^{* *}\end{array}$ & & & & & & $\begin{array}{c}8.48 \\
(2.4)^{*}\end{array}$ & & & & & & $\begin{array}{l}-1.02 \\
(0.5)\end{array}$ & & \\
\hline Age (yrs) & & & & & $\begin{array}{c}-5.97 \\
(2.6)^{* *}\end{array}$ & & & & & & $\begin{array}{l}0.53 \\
(0.2)\end{array}$ & & & & & & $\begin{array}{c}-7.04 \\
(2.5)^{* *}\end{array}$ & \\
\hline $\operatorname{Amt}(\mathrm{ml})$ & & & & & & $\begin{array}{l}-1.17 \\
(0.1)\end{array}$ & & & & & & $\begin{array}{c}-0.66 \\
(0.1) \\
-\end{array}$ & & & & & & $\begin{array}{l}0.01 \\
(1.4)\end{array}$ \\
\hline _cons & $\begin{array}{c}46.60 \\
(5.59)^{* *} \\
\end{array}$ & $\begin{array}{c}33.00 \\
(6.33) * * \\
\end{array}$ & $\begin{array}{l}-23.20 \\
(2.4)^{*}\end{array}$ & $\begin{array}{l}-44.69 \\
(3.48) * * \\
\end{array}$ & $\begin{array}{c}65.46 \\
(6.84)^{* *} \\
\end{array}$ & $\begin{array}{c}41.63 \\
(3.48)^{* *} \\
\end{array}$ & $\begin{array}{c}21.12 \\
(2.66) * * \\
\end{array}$ & $\begin{array}{l}49.52 \\
(1.93) \\
\end{array}$ & $\begin{array}{c}-24.60 \\
(2.82) * * \\
\end{array}$ & $\begin{array}{c}-55.71 \\
(2.65) * * \\
\end{array}$ & $\begin{array}{l}-1.27 \\
(0.11) \\
\end{array}$ & $\begin{array}{l}31.57 \\
(0.65) \\
\end{array}$ & $\begin{array}{c}59.04 \\
(8.63)^{* *} \\
\end{array}$ & $\begin{array}{c}64.13 \\
(12.9)^{* *} \\
\end{array}$ & $\begin{array}{l}79.10 \\
(3.9)^{* *}\end{array}$ & $\begin{array}{c}95.48 \\
(10.7)^{* *} \\
\end{array}$ & $\begin{array}{r}76.84 \\
(6.8) * * \\
\end{array}$ & $\begin{array}{l}60.20 \\
(6.5)^{* *}\end{array}$ \\
\hline Obs & 79983 & 79967 & 85384 & 85384 & 85384 & 85384 & 32613 & 32842 & 36508 & 36508 & 36508 & 36508 & 47370 & 47125 & 48876 & 48876 & 33192 & 48876 \\
\hline R-sqrd & 0.005 & 0.120 & 0.200 & 0.170 & 0.069 & 0.000 & 0.240 & 0.610 & 0.078 & 0.200 & 0.001 & 0.000 & 0.020 & 0.030 & 0.001 & 0.090 & 0.034 & 0.006 \\
\hline $\begin{array}{l}* \text { signific } \\
\text { Robust t }\end{array}$ & $\begin{array}{l}\text { ant at } 5 \% \\
\text { statistics }\end{array}$ & $\begin{array}{l}* * \text { sign } \\
\text { e in pal }\end{array}$ & $\begin{array}{l}\text { icant a } \\
\text { ntheses }\end{array}$ & & & & & & & & & & & & & & & \\
\hline
\end{tabular}

Table 6 : Univariate Pooled and Rating-Grouped Regressions of Average CDS - Par Equivalent Bond Basis on Bond Specific Liquidity

Related Variables: This table shows the unvaried pooled and rating grouped unbalanced panel regressions of monthly-averaged CDS-Par

Equivalent Bond Basis on bond specific liquidity variables.

The distribution of bonds by rating and country are reported in Tables 1 and 2 .

The t-statistics reported in parentheses are robust t-statistics with standard errors clustered by bond.

Data is obtained from Datastream. 


\begin{tabular}{|c|c|c|c|c|c|c|}
\hline \multicolumn{7}{|c|}{ Average CDS- bond Basis } \\
\hline & \multicolumn{2}{|c|}{ All Rating Grades } & \multicolumn{2}{|c|}{ Investment Grade } & \multicolumn{2}{|c|}{ Speculative Grade } \\
\hline \multirow{3}{*}{ Bid Ask Percent } & $\# 1$ & \#2 & $\# 1$ & $\# 2$ & $\# 1$ & \#2 \\
\hline & 0.09 & -4.24 & -14.29 & -17.40 & 4.93 & -4.54 \\
\hline & $(0.02)$ & $(0.91)$ & $(4.69)^{* *}$ & $(6.85)^{* *}$ & $(1.18)$ & $(0.78)$ \\
\hline \multirow[t]{2}{*}{ Turnover } & 0.79 & 0.82 & 1.02 & 1.02 & -0.03 & 0.06 \\
\hline & $(3.70)^{* *}$ & $(3.98)^{* *}$ & $(6.06)^{* *}$ & $(5.79)^{*}$ & $(0.15)$ & $(0.33)$ \\
\hline \multirow[t]{2}{*}{ Coupon } & 7.02 & 5.93 & 3.25 & 2.21 & 6.93 & 6.53 \\
\hline & $(6.91)^{* *}$ & $(5.13)^{* *}$ & $(2.45)^{*}$ & $(1.75)$ & $(4.42)^{* *}$ & $(3.93)^{* *}$ \\
\hline \multirow[t]{2}{*}{ Maturity (yrs) } & 9.38 & 9.50 & 3.77 & 3.60 & 13.34 & 13.63 \\
\hline & $(6.93)^{* *}$ & $(6.58)^{* *}$ & $(5.03)^{* *}$ & $(4.41)^{* *}$ & $(10.38)^{* *}$ & $(11.25)^{* *}$ \\
\hline \multirow[t]{2}{*}{ Age (yrs) } & -2.21 & -0.02 & -1.13 & -0.65 & -3.96 & -1.37 \\
\hline & $(1.60)$ & $(0.01)$ & (1.34) & $(0.86)$ & $(3.13)^{* *}$ & $(1.38)$ \\
\hline \multirow[t]{2}{*}{ Amount } & -0.01 & 0.00 & -0.01 & -0.01 & 0.00 & 0.00 \\
\hline & $(2.47)^{*}$ & $(0.91)$ & $(1.76)$ & $(1.82)$ & $(0.97)$ & $(0.22)$ \\
\hline \multirow[t]{2}{*}{ Moody`s Rating } & -6.85 & -6.50 & -3.11 & -0.18 & -5.02 & -5.26 \\
\hline & $(9.23)^{* *}$ & $(10.87)^{* *}$ & $(2.34)^{*}$ & $(0.10)$ & $(2.73)^{* *}$ & $(3.01)^{* *}$ \\
\hline \multirow[t]{2}{*}{ CDS Bid Ask } & & 1.07 & & 1.78 & & 0.93 \\
\hline & & $(3.11)^{* *}$ & & $(4.73)^{* *}$ & & $(2.76)^{* *}$ \\
\hline \multirow[t]{2}{*}{ CDS Bid Ask Pct } & & 0.14 & & -0.70 & & 0.14 \\
\hline & & $(6.53)^{* *}$ & & $(4.59)^{* *}$ & & $(6.14)^{* *}$ \\
\hline _cons & $\begin{array}{l}19.35 \\
(1.06)\end{array}$ & $\begin{array}{l}-1.96 \\
(0.11)\end{array}$ & $\begin{array}{l}18.74 \\
(0.61)\end{array}$ & $\begin{array}{l}-16.27 \\
(0.49)\end{array}$ & $\begin{array}{l}-16.69 \\
(0.87)\end{array}$ & $\begin{array}{l}-35.59 \\
(1.91)\end{array}$ \\
\hline Observations & 76420 & 76331 & 30714 & 30712 & 45706 & 45619 \\
\hline R-squared & 0.65 & 0.69 & 0.80 & 0.82 & 0.48 & 0.53 \\
\hline \multicolumn{7}{|l|}{$\begin{array}{l}* \text { significant at } 5 \% \\
* * \text { significant at } 1 \%\end{array}$} \\
\hline \multicolumn{7}{|c|}{ Robust t-statistics are in parentheses } \\
\hline
\end{tabular}

Table 7 : Pooled and Rating-Grouped Regressions of Average CDS - Par Equivalent Bond Basis

This table shows pooled and rating-grouped regressions of average CDS-Par Equivalent Bond Basis on various bond liquidity variables, CDS liquidity variables and ratings. While regression \#1 excludes CDS related liquidity variables, \#2 includes them. A brief explanation of the variables is provided in Table 3. The distributions of bond samples can be found in Table 1 and Table 2 and Figure 4.

Above regressions are unbalanced panels consisting of observations numbers reported in the tables. The t-statistics reported in parentheses are robust $t$-statistics with standard errors clustered by bond.

Data is obtained from Datastream. 


\begin{tabular}{|c|c|c|c|c|c|c|}
\hline \multicolumn{7}{|c|}{ Average CDS- bond Basis : Effects of Equity Market } \\
\hline & \multicolumn{2}{|c|}{ All Ratings } & \multicolumn{2}{|c|}{ Investment Grade } & \multicolumn{2}{|c|}{$\begin{array}{l}\text { Speculative } \\
\text { Grade }\end{array}$} \\
\hline & $\# 1$ & $\# 2$ & $\# 1$ & $\# 2$ & $\# 1$ & $\# 2$ \\
\hline Bid-ask Pct & $\begin{array}{l}-2.08 \\
(0.38)\end{array}$ & $\begin{array}{l}-7.18 \\
(1.43)\end{array}$ & $\begin{array}{l}-16.05 \\
(6.0)^{* * *}\end{array}$ & $\begin{array}{c}-17.52 \\
(7.48)^{* *}\end{array}$ & $\begin{array}{l}12.35 \\
(2.2)^{*}\end{array}$ & $\begin{array}{c}3.34 \\
(0.63)\end{array}$ \\
\hline Turnover & $\begin{array}{c}0.83 \\
(3.81)^{* *}\end{array}$ & $\begin{array}{c}0.83 \\
(3.77)^{* *}\end{array}$ & $\begin{array}{c}1.02 \\
(0.05)\end{array}$ & $\begin{array}{c}0.99 \\
(5.56)^{* *}\end{array}$ & $\begin{array}{c}0.00 \\
(0)\end{array}$ & $\begin{array}{l}-0.08 \\
(0.52)\end{array}$ \\
\hline Coupon & $\begin{array}{c}4.61 \\
(3.1)^{* *}\end{array}$ & $\begin{array}{c}3.65 \\
(2.01)^{*}\end{array}$ & $\begin{array}{c}1.89 \\
(1.13)\end{array}$ & $\begin{array}{c}2.02 \\
(1.31)\end{array}$ & $\begin{array}{c}9.05 \\
(5.75)^{* *}\end{array}$ & $\begin{array}{c}4.98 \\
(2.73)^{*}\end{array}$ \\
\hline Maturity (yrs) & $\begin{array}{c}8.15 \\
(5.81)^{* *}\end{array}$ & $\begin{array}{c}7.58 \\
(5.99)^{* *}\end{array}$ & $\begin{array}{c}3.49 \\
(4.09)^{* *}\end{array}$ & $\begin{array}{c}3.64 \\
(4.41)^{* *}\end{array}$ & $\begin{array}{c}11.99 \\
(7.92)^{* *}\end{array}$ & $\begin{array}{c}10.93 \\
(7.69)^{* *}\end{array}$ \\
\hline Age (yrs) & $\begin{array}{r}-1.10 \\
(0.9)\end{array}$ & $\begin{array}{l}-0.54 \\
(0.38)\end{array}$ & $\begin{array}{l}-0.31 \\
(0.46)\end{array}$ & $\begin{array}{l}-0.20 \\
(0.31)\end{array}$ & $\begin{array}{c}-4.60 \\
(3.39)^{* *}\end{array}$ & $\begin{array}{l}-2.92 \\
(1.92)\end{array}$ \\
\hline Amount & $\begin{array}{l}-0.01 \\
(1.81)\end{array}$ & $\begin{array}{l}-0.01 \\
(1.42)\end{array}$ & $\begin{array}{l}-0.01 \\
(1.86)\end{array}$ & $\begin{array}{l}-0.01 \\
(1.8)\end{array}$ & $\begin{array}{l}0.00 \\
(0.7)\end{array}$ & $\begin{array}{c}0.01 \\
(1.18)\end{array}$ \\
\hline Log Equity & $\begin{array}{c}-9.01 \\
(7.73)^{* *}\end{array}$ & $\begin{array}{c}-4.02 \\
(3.12)^{* *}\end{array}$ & $\begin{array}{l}-4.10 \\
(1.79)\end{array}$ & $\begin{array}{c}0.73 \\
(0.31)\end{array}$ & $\begin{array}{c}-13.27 \\
(5.27)^{* *}\end{array}$ & $\begin{array}{c}-4.26 \\
(3.14)^{* *}\end{array}$ \\
\hline Mkt & $\begin{array}{c}-13.34 \\
(4.41)^{* *}\end{array}$ & $\begin{array}{c}-5.68 \\
(2.03)^{*}\end{array}$ & $\begin{array}{l}-9.14 \\
(1.71)\end{array}$ & $\begin{array}{l}-2.74 \\
(0.59)\end{array}$ & $\begin{array}{c}-12.27 \\
(4.08)^{* *}\end{array}$ & $\begin{array}{c}-5.33 \\
(2.30)^{*}\end{array}$ \\
\hline CDS premium & & $\begin{array}{c}20.07 \\
(4.86)^{* *}\end{array}$ & & $\begin{array}{c}24.25 \\
(4.75)^{* *}\end{array}$ & & $\begin{array}{c}15.83 \\
(3.96)^{* *}\end{array}$ \\
\hline _cons & $\begin{array}{c}87.62 \\
(2.51)^{*}\end{array}$ & $\begin{array}{c}-0.03 \\
(0)\end{array}$ & $\begin{array}{l}49.46 \\
(1.01)\end{array}$ & $\begin{array}{l}-42.48 \\
(0.85)\end{array}$ & $\begin{array}{l}66.54 \\
(1.89)\end{array}$ & $\begin{array}{l}-17.35 \\
(0.57)\end{array}$ \\
\hline $\begin{array}{l}\text { Obs } \\
\text { R-sqrd }\end{array}$ & $\begin{array}{c}61691.00 \\
0.72\end{array}$ & $\begin{array}{c}61667.00 \\
0.78\end{array}$ & $\begin{array}{c}29704.00 \\
0.81\end{array}$ & $\begin{array}{c}29702.00 \\
0.83\end{array}$ & $\begin{array}{c}31987.00 \\
0.64\end{array}$ & $\begin{array}{c}31965.00 \\
0.72\end{array}$ \\
\hline $\begin{array}{l}* \text { * significant at } 5 \% \\
* * \text { significant at } 19\end{array}$ & & & & & & \\
\hline Robust t-statistics & e in parer & & & & & \\
\hline
\end{tabular}

Table 8 : Regressions of Average CDS- Par Equivalent Bond Basis : Effects of Equity Markets.

This table shows unbalanced panel regressions of the average basis on liquidity variables and MSCI emerging market equity indices by Morgan Stanley. Regression \#2 controls for CDS premiums. The index created by Morgan Stanley Capital International (MSCI) is designed to measure equity market performance in global emerging markets. The Emerging Markets Index is a float-adjusted market capitalization index.

The $\mathrm{t}$-statistics reported in parentheses are robust $\mathrm{t}$-statistics with standard errors clustered by bond.

Data is obtained from DataStream. 


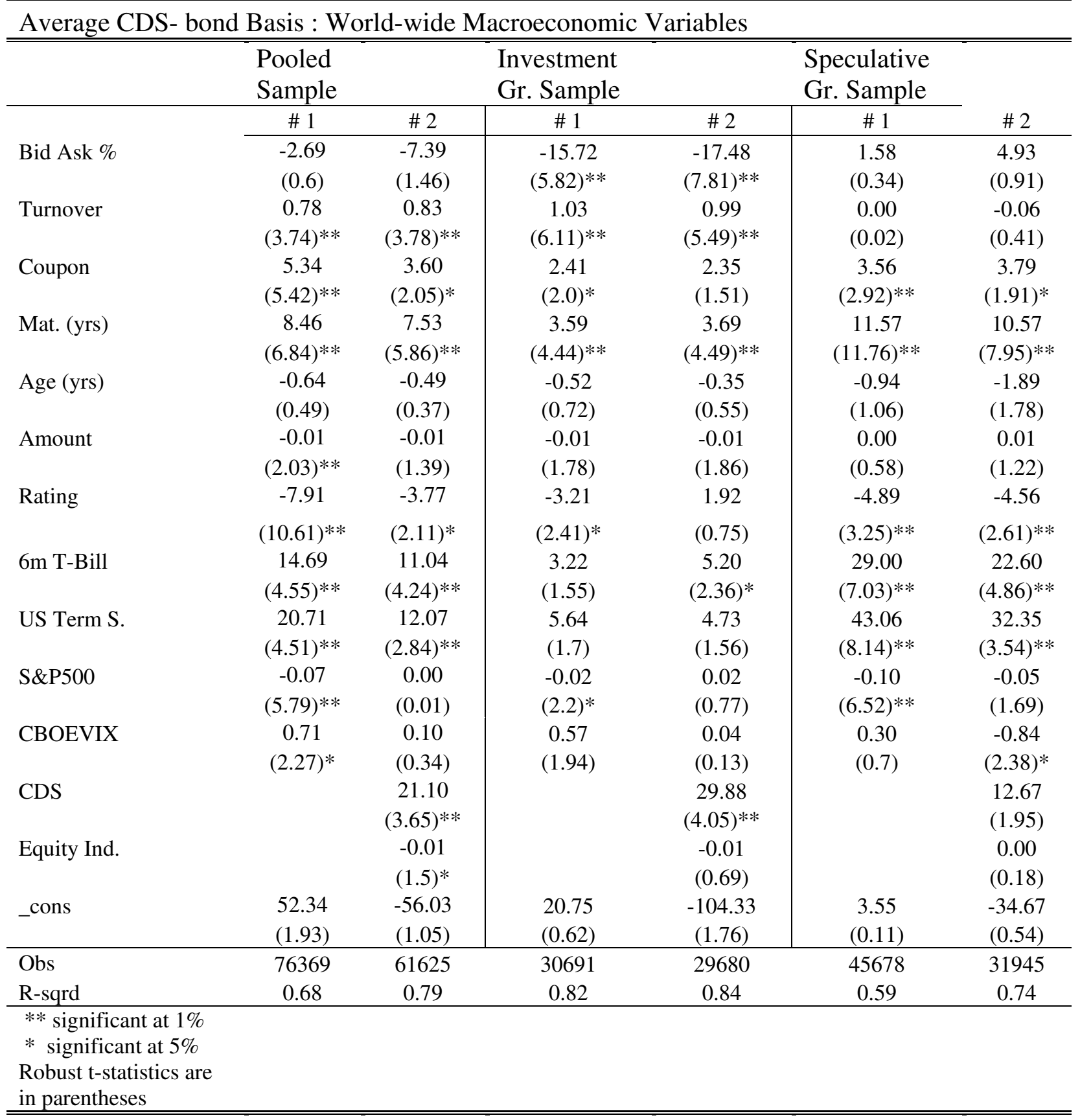

Table 9 : Regressions of Average CDS- Par Equivalent Bond Basis : Controlling for Macroeconomic Variables.

This table shows unbalanced panel regressions of the average basis on liquidity variables and macroeconomic variables including the 6-months T-bill rate, the term spread between 6-month and 10year T-bill rates, S\&P500 Composite Index, Chicago Board of Exchange S\&P 500 Option Volatility Index.

Regression \#2 controls for CDS and MSCI country equity market returns. A brief variable description is in Table 3. The t-statistics reported in parentheses are robust t-statistics with standard errors clustered by bond. Data is obtained from Datastream. 


\begin{tabular}{|c|c|c|c|c|c|c|}
\hline \multicolumn{7}{|c|}{ Par-Equivalent Basis with Fixed Effects } \\
\hline & \multicolumn{2}{|c|}{ Pooled Sample } & \multicolumn{2}{|c|}{ Investment Grade } & \multicolumn{2}{|c|}{ Speculative Grade } \\
\hline \multirow{3}{*}{ Bid-ask Pct } & \# 1 & $\# 2$ & \# 1 & $\# 2$ & $\# 1$ & $\# 2$ \\
\hline & 4.39 & 0.39 & -17.86 & -18.76 & 17.87 & 19.40 \\
\hline & $(0.63)$ & $(0.05)$ & $(3.72)^{* *}$ & $(4.32) * *$ & $(3.1)^{* *}$ & $(3.13)^{* *}$ \\
\hline \multirow[t]{2}{*}{ Turnover } & 0.74 & 0.76 & 0.96 & 0.96 & -0.12 & -0.16 \\
\hline & $(2.93)^{* *}$ & $(3.09)^{* *}$ & $(4.25)^{* *}$ & $(4.31)^{* *}$ & $(0.74)$ & $(1.23)$ \\
\hline \multirow[t]{2}{*}{ Coupon } & 6.64 & 4.39 & 4.59 & 3.50 & 6.83 & 5.44 \\
\hline & $(4.91)^{* *}$ & $(2.78)^{* *}$ & $(2.34)^{*}$ & $(1.61)$ & $(4.15)^{* *}$ & $(4.89)^{* *}$ \\
\hline \multirow{2}{*}{$\begin{array}{l}\text { Maturity } \\
\text { (yrs) }\end{array}$} & 8.91 & 7.32 & 4.18 & 3.88 & 12.01 & 10.59 \\
\hline & $(10.69)^{* *}$ & $(8.58)^{* *}$ & $(4.23)^{* *}$ & $(3.41)^{* *}$ & $(14.11)^{* *}$ & $(13.91)^{* *}$ \\
\hline \multirow[t]{2}{*}{ Age (yrs) } & -3.37 & -1.24 & -1.35 & -0.58 & -6.58 & -4.64 \\
\hline & $(3.33)^{* *}$ & $(1.26)$ & (1.68) & $(0.86)$ & $(6.88)^{* *}$ & $(5.46)^{* *}$ \\
\hline \multirow[t]{2}{*}{ Amount } & -0.01 & -0.01 & -0.01 & -0.01 & 0.00 & 0.00 \\
\hline & $(2.12)^{*}$ & (1.43) & (1.93) & (1.93) & $(0.65)$ & $(0.56)$ \\
\hline \multirow[t]{2}{*}{ Rating } & -39.34 & -87.50 & -3.51 & -5.75 & -18.89 & -43.31 \\
\hline & $(3.19)^{* *}$ & $(4.56)^{* *}$ & (1.59) & $(2.67)^{* *}$ & $(2.64) * *$ & $(2.95)^{* *}$ \\
\hline \multirow[t]{2}{*}{ Equity Mkt } & & -0.04 & & -0.01 & & -0.06 \\
\hline & & $(5.46)^{* *}$ & & (1.06) & & $(6.88)^{* *}$ \\
\hline \multirow{3}{*}{$\begin{array}{l}\text { Country Fix } \\
\text { _cons }\end{array}$} & YES & YES & YES & YES & YES & YES \\
\hline & 668.74 & 1627.09 & 20.63 & 63.01 & 52.74 & 471.39 \\
\hline & $(2.86)^{* *}$ & $(4.40)^{* *}$ & $(0.48)$ & $(1.58)$ & $(1.08)$ & $(2.81)^{* *}$ \\
\hline Obs & 76420 & 61691 & 30714 & 29704 & 45706 & 31987 \\
\hline R-sqrd & 0.69 & 0.75 & 0.82 & 0.82 & 0.55 & 0.71 \\
\hline
\end{tabular}

Table 10 : This table shows the results of unbalanced panel regressions of the parequivalent basis on various bond liquidity variables, MSCI equity market indices controlling for country fixed effects. A brief variable description is on Table 3 .

The t-statistics reported in parentheses are robust t-statistics with standard errors clustered by bond.

Data is obtained from Datastream. 


\section{Credit Curve Term Structure}

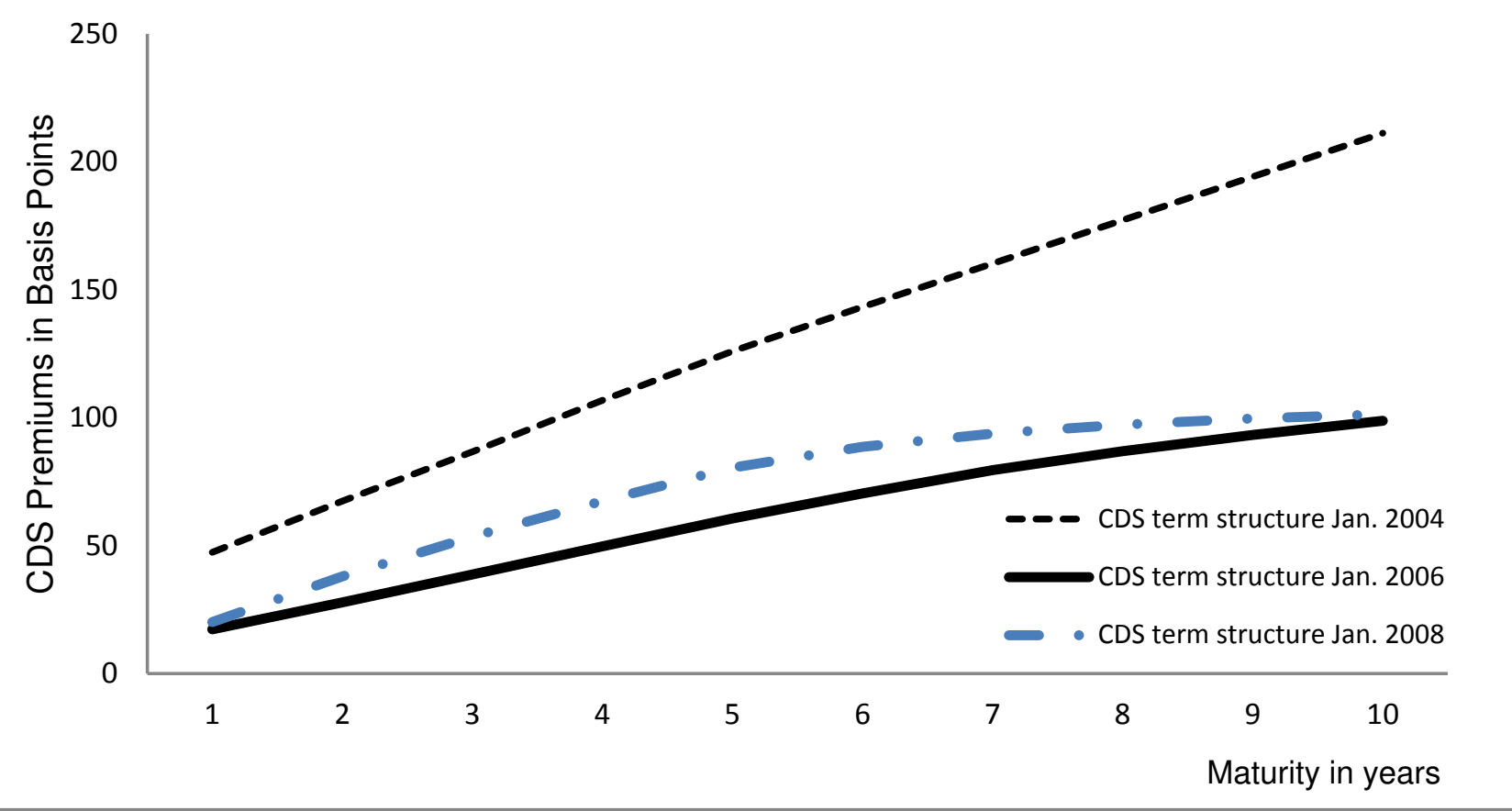

Figure 1: : Mexico 2004 and 2008 CDS term structure curves:

The purpose of this figure is to illustrate a common example of the term structure of credit curves of emerging market countries. As is clear from the credit curves, term structure of CDS is almost always positive. That is why it is extremely crucial to relax the "flat credit curve term structure" assumption. The CDS data is collected from Datastream, which distributes data from CMA. 


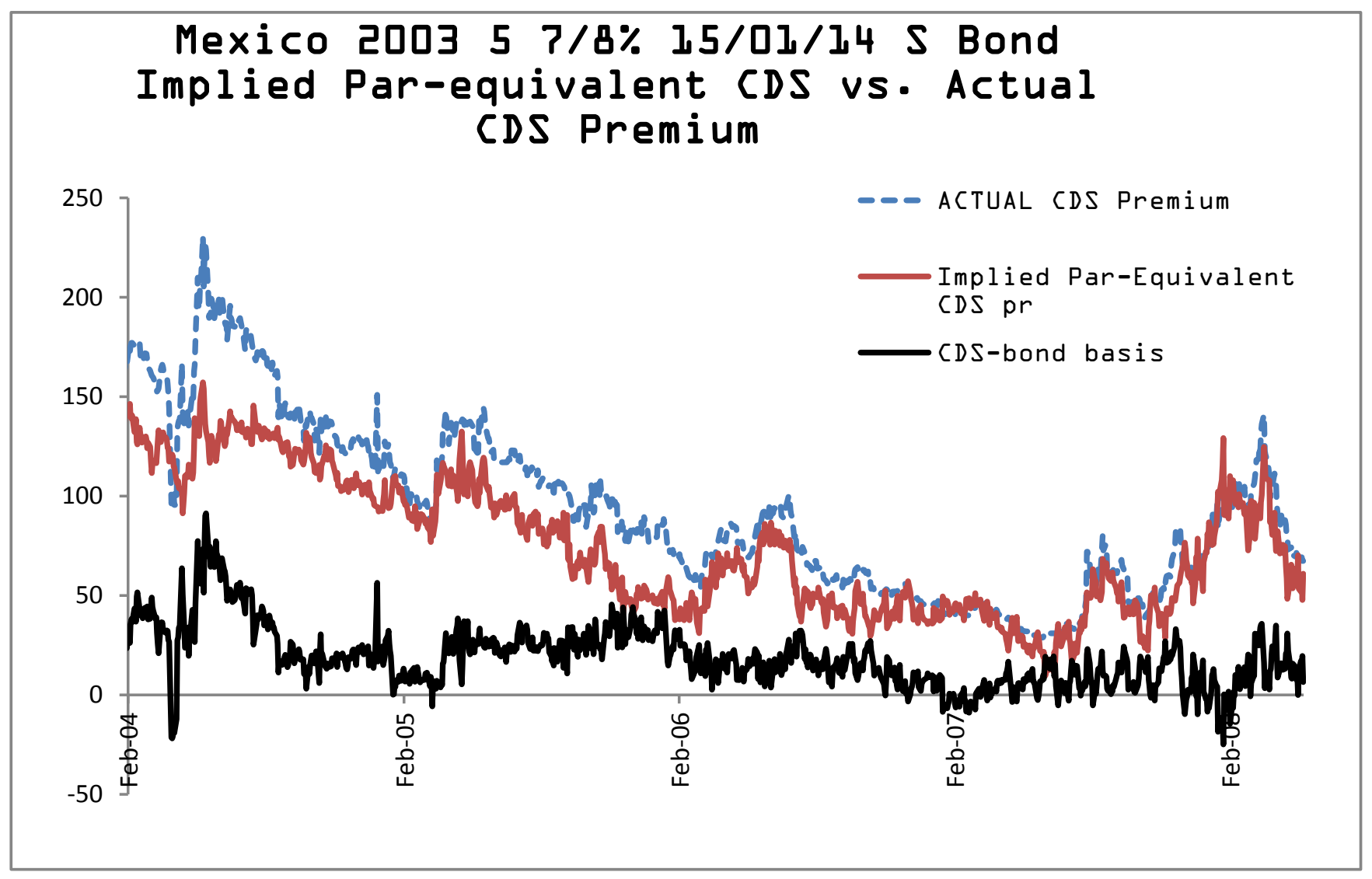

Figure 2: MEXICO. 20035 7/8\% 15/01/14 S Bond Implied Par-equivalent CDS premium vs. Actual CDS Premium.

This figure is an illustration of the calculated hypothetical par-equivalent CDS premium for one of Mexico's international bonds issued in 2003 and maturing in 2014. As explained in the text, for each day starting from January 1st 2004 until May 2008, I extract the average probability of default for the remaining maturity of the bond from bond yields using US swap curves as a risk free curve. Then, I calculate the par-equivalent CDS premium using the extracted default probability and maturity, which results in the blue dashed line in the above graph.

In my data set I have CDS maturities from 1 to 10 years. In order to compute the non-default component of the bond yields, I interpolate the CDS curve for the intermediate maturities, which results in the solid red line. My estimate of the non-default component is the difference between these two lines, i.e. the solid black line at the bottom is the CDS-bond basis.

The data is obtained from Datastream 

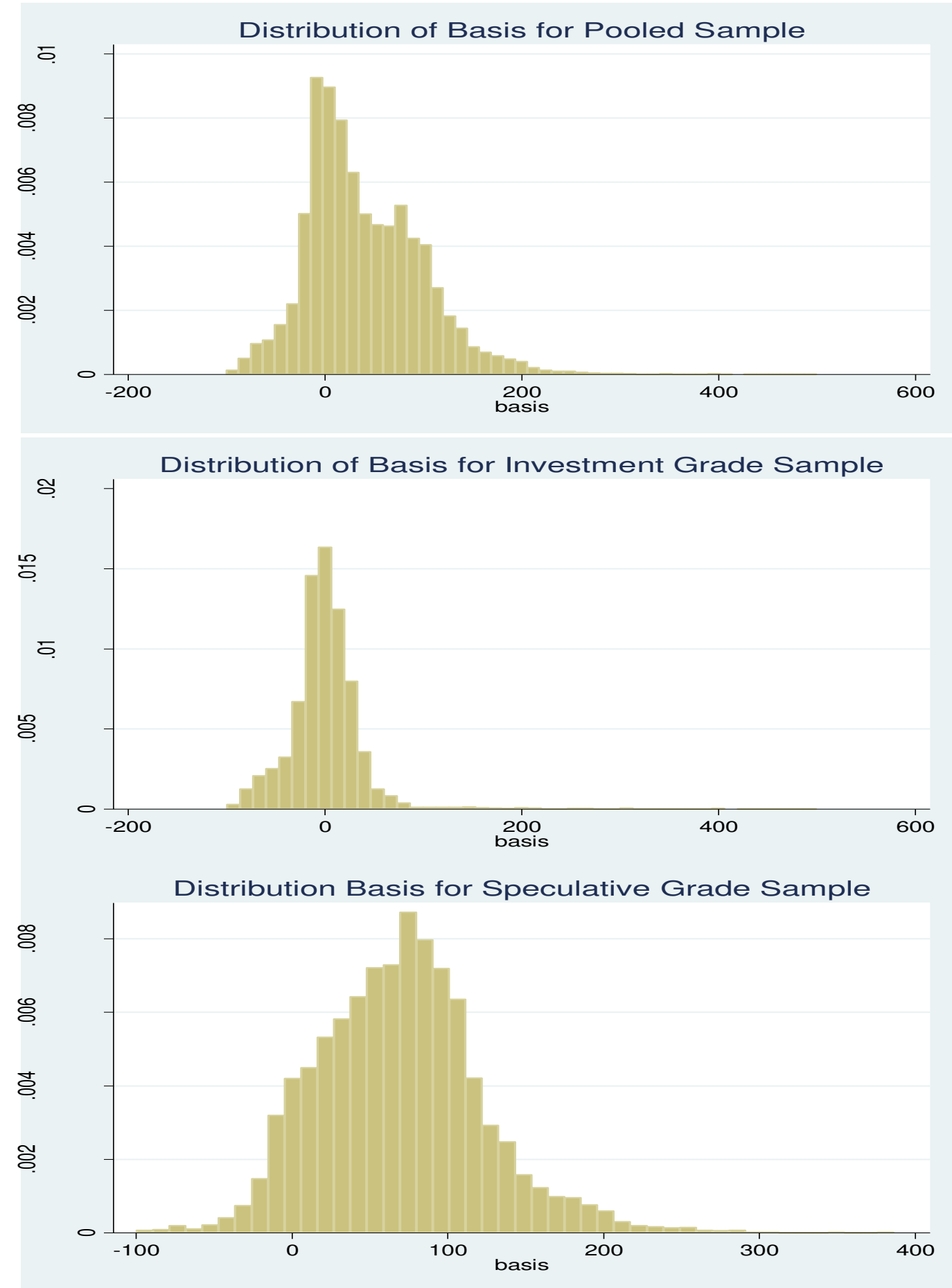

Figure 3: Distribution of CDS-Par Equivalent CDS Basis by Rating Groups.

These graphs show the distribution of the calculated CDS-bond basis, which is an estimate of the nondefault component of the emerging market sovereign bond yield spreads.

The data is obtained from Datastream. 

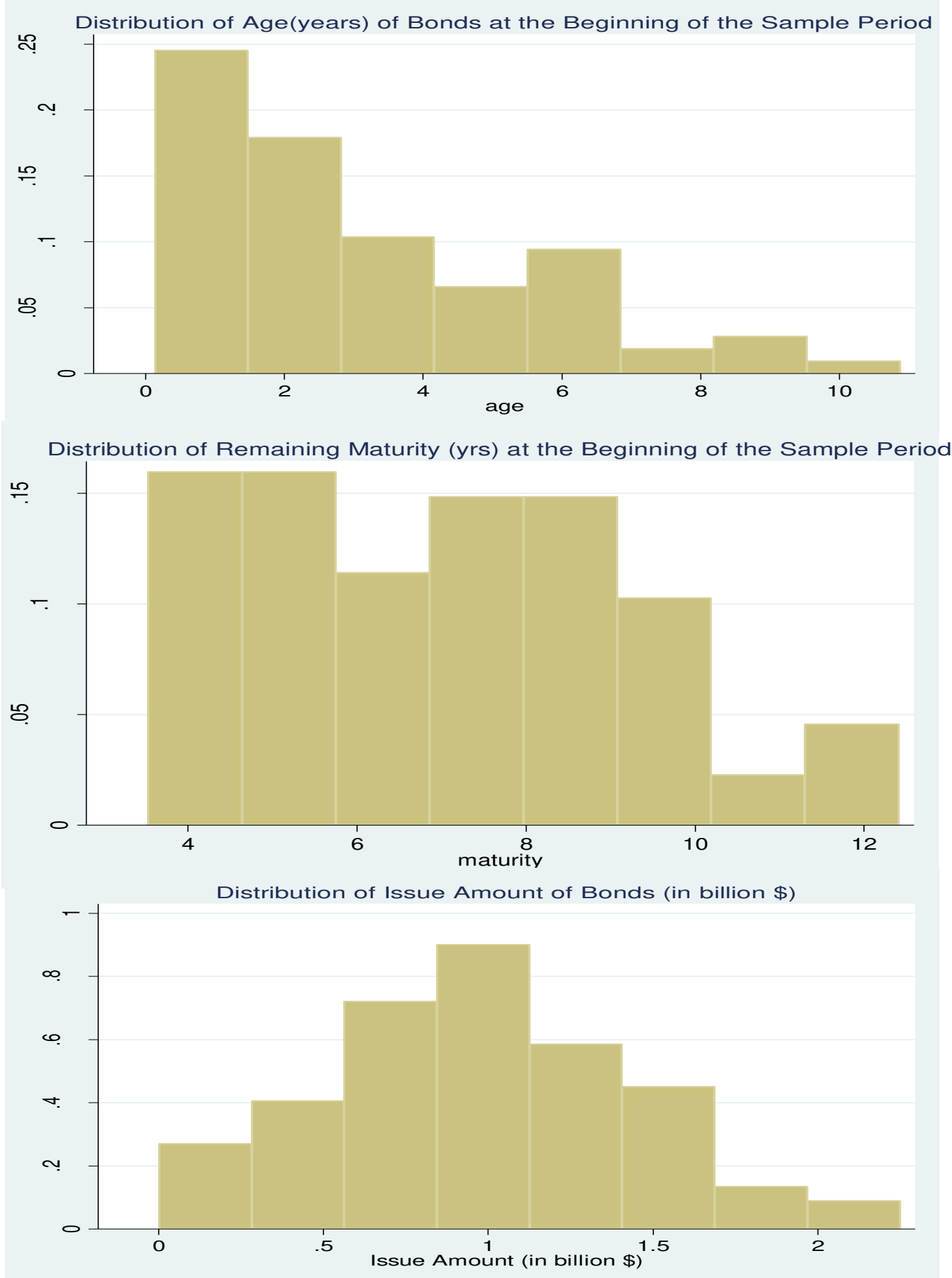

Figure 4: Distribution of Age, Remaining Maturity and Issue Amount of the Bond Sample. The purpose of this table is to present the audience a flavor of the distribution of the bond sample used in the regression analyses. Age variable is the time in years passed until the sample starting time of 2004. Remaining maturity is the remaining time in years until the bond expires. Issue amount variable is the amount of the bond issued by the emerging market sovereign in billions of US Dollars.

Data is collected from Datastream terminals. 